\title{
YACIMIENTOS NEOLÍTICOS EN EL RÍO CORBONES (SEVILLA)
}

\section{NEOLITHIC SITES IN THE CORBONES RIVER (SEVILLA)}

\author{
por \\ JOSÉ J. FERNÁNDEZ CARO \\ BEATRIZ GAVILÁN CEBALLOS
}

RESUMEN En el presente trabajo damos a conocer una serie de yacimientos situados en la margen derecha del curso medio del río Corbones, que cuentan con restos pertenecientes a distintos períodos de la Prehistoria, sobresaliendo los adjudicables al Neolítico no tanto por los materiales que han aportado como por la constatación del citado período en terrenos abiertos de campiña. De otro lado, la presencia de dicha etapa en esta zona ayuda a comprender mejor la ocupación generalizada de este tipo de terreno durante la etapa siguiente, el Calcolítico, al tiempo que permite desterrar la concepción de un Neolítico principalmente serrano y con hábitats en cuevas y/o abrigos rocosos.

\begin{abstract}
In the following paper our aim is to make a series of sites situated along the right of the mid section of the Corbones River known, which contain remains pertaining to distinct periods in Prehistoric times, notably those corresponding to the Neolithic not so much for the matter found as for the demostration the said period exists in the open tracts of arable land between Carmona and Córdoba, ie. the "Campiña". The importance of these finds is, at any rate, considerable if we take into account the scarcity of sites in the open air with Neolithic remains. On the other hand, the presence of said period in the "Campina" aids us in better understanding the generalized inhabitance of this type of terrain during the following period, Copper Age, while permiting us to banish the concept of a exclusively mountainous Neolithic and with habitats predominantly in caves and/or cliff dwellings.
\end{abstract}




\section{INTRODUCCIÓN}

Por el momento, se han detectado restos neolíticos en un total de tres yacimientos situados en terrenos abiertos de campiña, en la margen derecha del río Corbones: Las Barrancas, Los Alamos y San Pedro, siendo el primero de ellos el que ha proporcionado mayor número de items pertenecientes a este período, contando también con restos adjudicables a otras etapas de la Prehistoria ${ }^{1}$. Por su parte, Los Alamos ha ofrecido, además de materiales neolíticos, calcolíticos y de la Edad del Bronce, un cuantioso volumen de industria lítica tallada que hemos considerado oportuno dividir en dos grandes grupos. Por un lado, un conjunto de elementos con pátina fresca entre los que aparecen piezas de clara adscripción postpaleolítica, que son los que presentamos en este estudio y, por otro, una gran masa de productos de talla con una pátina blanquecina y connotaciones tipológicas superopaleolíticas, conjunto éste cuyo estudio ofreceremos en un trabajo independiente por la entidad de dichos restos. Por último, el yacimiento de San Pedro es el que cuenta con menor número de restos que, aunque con ciertas reservas, nos permite detectar la posible presencia de Neolítico en este lugar. Un cuarto yacimiento, Loma Lombriz II, que sólo proporcionó un fragmento de brazalete de piedra pulimentada, lo mantenemos como probable ya que no hemos conseguido obtener nuevos elementos que facilitasen su definitiva adscripción. Todos estos yacimientos han sido objeto de una prospección sistemática no selectiva.

Queremos dejar constancia de que Los Alamos y San Pedro forman parte de un mismo conjunto de cerros, denominados "Cerros de San Pedro" (Fernández Caro 1992), separados por una distancia de $1 \mathrm{~km}$.

Ante la imposibilidad de ofrecer un estudio estadístico de cada uno de los conjuntos industriales presentes en los distintos yacimientos objeto de este trabajo, nos hemos visto en la necesidad de acudir a una descripción convencional de aquellos cuyo número de fragmentos no permite el empleo de la estadística; por el contrario, de los que sí contamos con mayor volumen se abordan mediante este tipo de análisis, ofreciendo sus características generales en cuadros.

Antes de comenzar, queremos indicar que, puesto que no hemos encontrado en la bibliografía al uso una definición clara y consensuada que establezca las diferencias entre la cerámica incisa y la acanalada, hemos optado por atenernos a un parámetro métrico, de tal manera que consideramos incisas a aquellas cuya anchura de surco no supera los $2 \mathrm{~mm}$. de grosor, reservando la denominación de acanalada para las que alcanzan de dicha medida en adelante.

\section{LAS BARRANCAS}

Este yacimiento se localiza en las coordenadas $437,20 / 317,15$, dentro del término municipal de Carmona. Se encuentra al W. del Cortijo de Las Barrancas, en la margen derecha del río Corbones. Ocupa una extensión de unos $300 \mathrm{~m}^{2}$ sobre una elevación testigo de la terraza superopleistocénica, situada a $+18 \mathrm{~m}$. del nivel del agua, divisándose desde este lugar toda la zona W. de la llanura del Corbones.

1. Estos yacimientos han sido detectados gracias al trabajo de prospección efectuado por J.J. Fernández Caro, quien, con los permisos y subvenciones de la Dirección General de Bienes Culturales de la Consejería de Cultura de la Junta de Andalucía, realizó la prospección correspondiente al término de Fuentes de Andalucía y zonas aledañas en 1984 y desde 1987 hasta la actualidad en la cuenca del río Corbones, con objeto de establecer su secuencia paleolítica. Resultado de tales trabajos fueron los estudios "Avance sobre la Carta Arqueológica de la comarca de Fuentes de Andalucía (Sevilla)" A.A.A. 1985: 109113. Sevilla, 1987; y Carta Arqueológica del término de Fuentes de Andalucía (Sevilla), Ayuntamiento de Fuentes de Andalucía, 1992. 
El material recuperado alcanza un total de 280 items, que se distribuyen de la siguiente manera:
A.- Industria lítica tallada
B.- Piedra pulimentada
C.- Cerámica

TOTAL

\begin{tabular}{|c|c|}
\hline 95 & $33,92 \%$ \\
\hline 2 & $0,71 \%$ \\
\hline 183 & $65,37 \%$ \\
\hline 280 & $100,00 \%$ \\
\hline
\end{tabular}

\section{A.- INDUSTRia Lítica Tallada}

Como se ha comentado en la introducción, las características del yacimiento hacen que existan graves problemas a la hora de definir la industria tallada. El hecho de situarse sobre una terraza fechada en el Pleistoceno Superior, desmontada en parte por la acción del arado, ha hecho que se mezclen las industrias mediopaleolíticas (de cuya existencia no nos cabe la menor duda al haber sido encontradas algunas de ellas en conexión con los paquetes detríticos aluviales fechados en el Pleistoceno Superior) (Baena 1993) con las que debieron pertenecer a los grupos que fabricaron las cerámicas. Por otro lado, se ha detectado un potente yacimiento a escasos metros del que nos ocupa, con un desarrollo controlado desde el Bronce hasta el mundo musulmán, con escasas lagunas culturales, y cuyos restos han podido contaminar el espacio estudiado, como parece deducirse de algunos fragmentos de cerámica común muy similares a los de los momentos citados (Rodríguez Temiño 1984).

El grado de rodamiento y la pátina creemos que son los únicos elementos en los que nos podemos apoyar para poder separar las industrias paleolíticas de las posteriores. Así las pleistocenas presentan, en general, un desgaste de arista que podríamos considerar menor, mientras que las holocenas (tomando como elemento base las láminas anchas y muy anchas de sección trapezoidal, que presuponemos no paleolíticas, así como los elementos de hoz) aparecen con aristas vivas, con algún grado de desilificación, probablemente por su exposición a los agentes atmosféricos.

No obstante, no podemos garantizar la procedencia holocénica de todos y cada uno de los elementos analizados en el presente estudio ya que, desgraciadamente, no han sido hallados en estratigrafía.

Del yacimiento de Las Barrancas proceden un total de 95 piezas líticas talladas (33,92\% del total de los conjuntos industriales) que se reparte de la siguiente manera:

\section{- Material Sin Retocar \\ - Material Retocado TOTAL}

$$
\begin{array}{rrr}
56 & 58,95 \% \\
39 & 41,05 \% \\
\cline { 1 - 1 } 95 & 100,00 \%
\end{array}
$$

Ambos conjuntos se distribuyen como sigue:

$\begin{array}{lcccc} & \text { Piezas } & \text { Mat. S/Ret. } & \text { Mat.Ret. } & \text { Total Ind. } \\ \text { - Núcleos } & 17 & 30,35 \% & (-) & 17,89 \% \\ \text { - Lascas } & 31 & 55,37 \% & (-) & 32,66 \% \\ \text { - Hojas } & 8 & 14,28 \% & (-) & 8,42 \% \\ \text { - Dientes de hoz } & 8 & (-) & 20,53 \% & 8,42 \% \\ \text { - Muescas } & 8 & (-) & 20,53 \% & 8,42 \% \\ \text { - Denticulados } & 5 & (-) & 12,82 \% & 5,26 \% \\ \text { - Truncaduras } & 4 & (-) & 10,25 \% & 4,21 \%\end{array}$




\begin{tabular}{|c|c|c|c|c|}
\hline & Piezas & Mat. S/Ret. & Mat.Ret. & Total Ind. \\
\hline - Perforadores & 2 & $(-)$ & $5,12 \%$ & \\
\hline - Raederas & 2 & $(-)$ & $5,12 \%$ & $2,10 \%$ \\
\hline - Retoque simple & 5 & $(-)$ & $12,82 \%$ & $5,26 \%$ \\
\hline - Astillados & 1 & $(-)$ & $2,56 \%$ & $1,05 \%$ \\
\hline - Diversos & 4 & $(-)$ & $10,25 \%$ & $4,21 \%$ \\
\hline TOTAL & 95 & $100,00 \%$ & $100,00 \%$ & $100,00 \%$ \\
\hline
\end{tabular}

- Material Sin Retocar: Con un total de 56 piezas, alcanzan el 58,95\% del total de la industria lítica tallada.

- Núcleos: Ascienden a 17 y todos son en sílex.

De talla centrípeta: Dos para lascas. Prismáticos: Uno para lascas; probablemente sobre lasca muy espesa.

Con un plano de golpeo: Cinco para laminillas estrechas y muy estrechas (Bagolini 1968)). Con dos planos de golpeo opuestos: Dos para laminillas estrechas y muy estrechas.

Uno sobre lasca de semidescortezado. Diversos, contabilizamos seis.

- Lascas: 31. Se han detectado 1 lasca de descortezado, 14 de semidescortezado y 14 ordinarias. Así mismo se han recogido dos lascas levallois atípicas, una de forma rectangular y la otra, trapezoidal.

- Hojas: Se han recogido 8 fragmentos de hojas, de los cuales 4 son proximales y 4 mediales. Sus anchuras se establecen en la siguiente tabla:

$\begin{array}{ccc} & \text { Fragm. prox. } & \text { Fragm. med. } \\ 10-14 \mathrm{~mm} . & 1 & 2 \\ 15-19 \mathrm{~mm} . & 2 & 1 \\ 20-25 \mathrm{~mm} . & 1 & 1\end{array}$

Talones productos sin retocar:

Los 35 talones detectados (recuérdese que en las hojas hemos contabilizado 4 mediales que, como es lógico, no presentan talón) se clasifican como sigue: 5 lisos corticales $(14,28 \%), 21$ lisos internos (60\%), 3 facetados $(8,57 \%), 2$ diedros $(5,71 \%), 2$ puntiformes $(5,71 \%)$, y 2 filiformes $(5,71 \%)$. Estos últimos probablemente procedentes de planos lisos.

La observación de estos talones ha permitido conocer que algo más de la mitad presentaban pequeñas extracciones en la zona dorsal del talón resultado del rebaje de la cornisa que aparecen en núcleos al extraer lascas o láminas previas. Con ello no sólo se consigue una mejor zona de gopleo o apoyo, sino también que la lámina o lasca posea un talón delgado: 1 en los lisos corticales (20\%), lo cual debe considerarse normal dadas las características de estas lascas; 11 en los lisos internos $(52,38 \%) ; 1$ en los facetados (33, 33\%); 2 en los diedros (100\%); 1 en los puntiformes (50\%); y 2 en los filiformes $(100 \%)$.

Dada la existencia de una relativa presencia de piezas obtenidas a partir de restos de talla antiguos, hemos considerado oportuno incluir entre los corticales o semicorticales aquellos restos que presentan en algunas de sus caras elementos suficientes para considerarlos como procedentes de útiles o restos anteriores: diferente pátina o grado de redondeamiento en sus aristas. 
- Material Retocado: 39.

- Dientes de hoz: Hemos contabilizado 8 elementos de hoz, 1 en cuarcita y los restantes en sílex. El de cuarcita, así como uno de los de sílex presentan la fisonomía de los de media luna, y tienen la característica común de haber sido tallados sobre lascas corticales, por lo que una de sus caras es totalmente cortical. Los otros están realizados sobre lascas (3), lasca laminar (1) y láminas (2) presentando dorso opuesto al filo dentado y extremos con truncaduras, fracturas retocadas y fracturas sin retocar. Uno de ellos presenta lustre de cereal.

- Muescas: 8 piezas: 4 retocadas y 4 ejemplares del tipo clactoniense (simples).

- Denticulados: 5, todos sobre lasca. Dos presentan retoque directo, dos inverso y una alternante. Todos se han formado a partir de dos muescas retocadas continuas, con retoque simple (3) y semiabrupto (2).

- Truncaduras: Se han detectado 4 lascas con retoque en extremo. Una sobre lasca levallois recurrente. Presenta retoque abrupto directo que delimita una truncadura distal recta levemente inclinada al eje de lascado. El lado izquierdo presenta un retoque bifacial marginal que produce un microdenticulado, mientras que el derecho posee un retoque semiabrupto marginal dejando otro microdenticulado. De las otras tres, dos aparecen sobre lasca, una de semidescortezado y la otra interna, presentando la primera retoque abrupto mientras la segunda retoque simple margịnal. La tercera se ha formado sobre una pequeña lasca laminar con retoque en extremo simple.

- Perforadores: 2 perforadores se han hallado en este conjunto: uno típico y otro atípico. Uno sobre lasca laminar y el otro sobre lasca. Ambos presentan un lado con retoque abrupto, y el otro con retoque simple en un caso y retoque marginal en el otro caso.

- Raederas: Se han contabilizado 2 raederas, una lateral, sobre lasca laminar espesa de semidescortezado, presentando retoque simple directo en el lado izquierdo y la otra transversal sobre lasca de semidescortezado, con retoque simple directo.

- Piezas con retoque simple: 5. Dos fragmentos de, posiblemente, lascas laminares, con retoque simple continuo inverso marginal que ocupa parte de sus respectivos lados izquierdos. Una pequeña lasca muy ancha y una microlasca ancha con retoque simple continuo directo marginal ocupando sus respectivos lados distales. Un fragmento de laminilla con retoque simple continuo directo marginal que ocupa parte de su lado derecho.

- Astillados: 1

- Diversos: 4. Un fragmento distal de laminilla estrecha con dos huellas de retoque simple directo en su extremo distal que afecta oblicuamente a su mitad derecha.

Dos microlascas anchas con dos golpes de retoque simple, continuo, directo uno, inverso el otro, que afecta muy parcialmente a uno de sus lados.

Una lasca espesa con una extracción cuya huella presenta una concavidad que a su vez, presenta huellas de uso como muesca.

Talones productos retocados:

De los 39 útiles detectados, $10(25,64 \%)$ presentan talón cortical; $23(58,97 \%)$ talón liso interno; $4(10,26 \%)$ facetado; $1(2,56 \%)$ talón diedro y $1(2,56 \%)$ filiforme. 


\section{B.- Piedra Pulimentada}

Dentro de este apartado contamos con un fragmento proximal de hacha y una azuela prácticamente completa, que alcanzan sólo el $0,71 \%$ del total de la industria procedente de este yacimiento. Ambas presentan un buen pulimento.

\section{Consideraciones sobre el material lítico}

El conjunto que hemos podido reunir en relación con el espacio donde se ha recogido la cerámica decorada es escaso y, como hemos visto, poco definidor de un momento cultural determinado.

Con respecto a la materia prima, hemos podido comprobar que el sílex es prácticamente exclusivo (sólo contamos con un útil, un elemento de hoz en cuarcita). Aunque tenían la posibilidad de usar cuarcita, común en coluviones cercanos a unos $2 \mathrm{~km}$., el sílex ha sido la materia prima dominante. Tal soporte pudieron encontrarlo en el mismo río, en cuyos aportes se pueden encontrar cantos pequeños y medianos de esta roca $(5-10 \mathrm{~cm}$. de diámetro).

Los núcleos ponen de manifiesto, por un lado, el predominio de extracciones laminares y microlaminares, y por otro una tipología que se ajusta a las características formales de los núcleos procedentes de conjuntos neolíticos medios y finales.

En cuanto a los productos de talla no retocados, comprobamos que las lascas son mayoritarias, y sorprende la ausencia de microlaminillas y laminillas estrechas, cuyas huellas son comunes en los núcleos. Aunque las hojas tienen una sostenida presencia, su tipometría aleja la posibilidad de relacionarlas con los núcleos encontrados. Tecnológicamente hay un claro dominio de los talones lisos, lo cual se corresponde con los planos de golpeo detectados en los núcleos. Por otro lado detectamos cómo un alto porcentaje (58\%) de los productos de talla ha conocido un rebaje de su charnela previo a su extracción.

Por lo que respecta a los útiles tipológicos, la presencia de perforadores, raederas, muescas, denticulados y truncaduras, no facilita una cronología. Por otro lado, el alto porcentaje de elementos de hoz, la presencia entre ellos de los de tipo de media luna, y la relación de láminas muy anchas y anchas favorecen su adscripción a un momento indefinido del Calcolítico.

Por su parte, en lo que se refiere a la piedra pulimentada, las piezas con que contamos tampoco ayudan a precisar la adjudicación cultural, considerando que, como en el caso anterior, podemos estar ante elementos tanto neolíticos como calcolíticos o, quizá, más nuevos. No obstante, sí debemos destacar su escasa presencia, así como la ausencia absoluta de molinos.

Una vez más se pone de manifiesto la dificultad que representa el trabajar con conjuntos recogidos en superficie. Posiblemente nos hallamos con unas industrias mezcladas correspondientes a dos, al menos, períodos culturales: Neolítico y Calcolítico o Bronce, aunque dada la tipología de las láminas, más cercano al Cobre que al Bronce. Habrá, pues, que esperar al análisis de la cerámica para definir el o los períodos culturales a los que se adscriba el conjunto. 


\section{C.- Cerámica}

El conjunto industrial cerámico del yacimiento de Las Barrancas consta de un total de 183 fragmentos, que suponen el $65,37 \%$ del total del material procedente de este asentamiento.

Teniendo en cuenta las características, las formas y la factura hemos determinado la existencia de fragmentos pertenecientes a distintas etapas culturales de la Prehistoria. El lote más numeroso lo integran una serie de restos perfectamente adjudicables al Neolítico (115 items), que alcanza el 62,85\% del total y el $70,14 \%$ del material selecto.

Incluso en el caso de la cerámica no decorada, en la que resulta más difícil en ocasiones determinar la adscripción cultural, se advierten claramente dos grupos: uno con características semejantes a las neolíticas que aparecen en las cuevas con ocupación de este período (que son las que incluimos en el apartado anterior), y otro, de factura más tosca, que comparte rasgos comunes a las procedentes de yacimientos de la Edad de los Metales en general.

Al Calcolítico, posiblemente, y la Edad del Bronce corresponde el 25,68\% del total (47 fragmentos) y el $28,65 \%$ del selecto. Por las características y la tipología que ofrecen, podemos indicar que, la mayoría, parecen apuntar a una asignación calcolítica; no obstante, contamos con determinados fragmentos adjudicables a etapas más avanzadas, ya dentro del Bronce Final.

Contamos, también, con dos fragmentos de cerámica decorada mediante engobe, suponiendo esta especie el $1,09 \%$ del total del material cerámico y el $1,21 \%$ del selecto.

El 10,38\% del conjunto cerámico que resta pertenece a los atípicos sin decorar, que resultan difíciles de encuadrar en una determinada etapa cronológica y/o cultural.

La presencia de cerámicas adscribibles a distintos períodos nos ha impulsado, lógicamente, a analizar dichos conjuntos por separado, ofreciendo su estudio porcentual individualizadamente.

\section{- Cerámica adjudicable al Neolítico}

Hemos incluido como perteneciente a esta etapa de la Prehistoria un conjunto de fragmentos de clara tipología y características neolíticas que se diferencian netamente del resto del material, tanto por sus decoraciones y formas de las vasijas, como por la factura de la pasta.

Contamos, pues, con un total de 115 piezas que se reparten de la siguiente manera:

$\begin{array}{lcccc} & \text { Material } & \text { Selecto } & \text { Material } & \text { Decorado } \\ \text { - Almagra } & 89 & 77,43 \% & 89 & 83,20 \% \\ \text { - Acanalada } & 7 & 6,08 \% & 7 & 6,54 \% \\ \text { - Incisa } & 6 & 5,21 \% & 6 & 5,60 \% \\ \text { - D.P.A } & 3 & 2,60 \% & 3 & 2,80 \% \\ \text { - Impresa } & 2 & 1,73 \% & 2 & 1,86 \% \\ \text { - No Decorada } & 9 & 6,95 \% & \frac{(-)}{n} & \frac{(-)}{100,00 \%}\end{array}$

\section{Cerámica a la Almagra}

Como se aprecia claramente en el esquema superior, se da un claro predominio de la cerámica a la almagra sobre el resto de las especies presentes en este yacimiento, alcanzando el $77,43 \%$ del total del material selecto y el $83,20 \%$ del decorado. Las características generales de esta especie quedan reflejadas en los siguientes cuadros: 
- Superficies:

Bruñida

Espatulada

Alisada Muy Fina

Alisada Fina

Alisada

Alisada Tosca

Tosca

Muy Tosca

Erosionada.

- Desgrasantes:

No Apreciables

Muy Finos

Finos

Medios

Gruesos

Muy Gruesos

- Pigmento:

Anaranjado

Bermellón

Carmín
Ext.

$33,73 \%$

$1,12 \%$

$25,84 \%$

$20,22 \%$

$16,85 \%$

$2,24 \%$

$(-)$

$(-)$

$\frac{(-)}{100,00 \%}$
Int.

$12,35 \%$

$1,12 \%$

$22,47 \%$

$29,25 \%$

$14,60 \%$

$10,11 \%$

$3,37 \%$

$2,24 \%$

$\frac{4,49 \%}{100,00 \%}$
- Cocción:

Reductora

Oxidante

Nervio

Alternante

- Espesores:

$-6 \mathrm{~mm}$

6-9 mm

9-12 mm

$+12 \mathrm{~mm}$

- Color:

Marrón

Negro

$17,97 \%$

$43,85 \%$

$25,84 \%$

$7,86 \%$

$\frac{2,24 \%}{100,00 \%}$
Ext.

$68,54 \% \quad 66,30 \%$

$\frac{31,46 \%}{100,00 \%} \quad \frac{33,70 \%}{100,00 \%}$
$69,68 \%$

$7,86 \%$

$4,49 \%$

$\frac{17,97 \%}{100,00 \%}$

$3,37 \%$

$51,70 \%$

$32,58 \%$

$\frac{12,35 \%}{100,00 \% \text {. }}$

Ext. Int.

$31,46 \% \quad 48,22 \%$

$60,68 \% \quad 44,64 \%$

$\frac{7,86 \%}{100,00 \%} \quad \frac{7,14 \%}{100,00 \%}$

- Tipos de fragmentos:

Bordes

$22,47 \%$

$1,12 \%$

$1,12 \%$

S.P.S

$\frac{74,17 \%}{100,00 \%}$

- Forma de los labios:

Redondeados

Semiplanos

Planos

Redondeados-apuntados

Biselados

Indicado
$50 \%$

$20 \%$

$15 \%$

- Bordes:

\section{Entrantes}

Salientes

Rectos

No determ

$$
\begin{array}{r}
37,07 \% \\
00,00 \% \\
62,93 \% \\
\hline 100,00 \%
\end{array}
$$

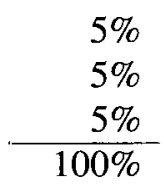

Los escasos fragmentos que nos han permitido hallar la dimensión del diámetro ofrecen principalmente unas medidas de tipo medio (seis ejemplares), comprendidas entre los $11-17 \mathrm{~cm}$., existiendo dos 
ejemplares que superan dichas dimensiones, uno entre $25-30 \mathrm{~cm}$. y el otro entre $30-35 \mathrm{~cm}$. Sólo contamos con un S.P.S., tratándose de un asa acodada.

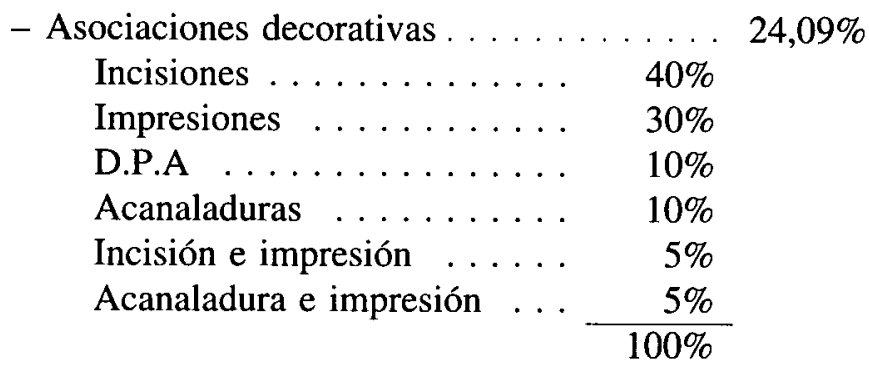

Tanto el tamaño como la presión de las incisiones asociadas a almagra son, predominantemente, medios, quedando reducida la temática casi invariablemente a líneas horizontales (fig. 2: 72; fig. 3: 23).

Por su parte, las acanaladas presentan, además de líneas horizontales, bandas de líneas quebradas, horizontales y verticales, que podrían llegar a formar motivos geométricos de tipo greca (fig. 3: 61).

Como en el caso anterior, cuando la almagra está asociada a impresiones la temática es muy homogénea, apareciendo únicamente los motivos circulares, a base de bandas dobles o simples, que se localizan generalmente en el labio y en el borde (fig. 2: 40, 32 y 28), existiendo un ejemplar que presenta impresiones circulares en el labio, borde y galbo (fig. 2: 17). El tamaño de estas impresiones suele ser medio y la presión profunda.

En cuanto a las asociaciones con D.P.A., contamos con un cordón exterior liso y vertical y otro, interior, e inciso horizontal que podríamos considerar como un cordón interior de refuerzo.

Por último, tenemos almagra asociada a impresiones e incisiones en un ejemplar (fig. 3: 129). Las impresiones, ovaladas, se encuentran en el borde y, a continuación, se suceden líneas incisas horizontales. Igualmente, tenemos un ejemplar en el que se combinan tres sistemas decorativos: almagra, acanaladuras e impresiones (fig. 3: 3); las acanaladuras las forma una banda de líneas horizontales y verticales, tendente a la greca, mientras que las impresiones ofrecen motivos circulares que describen una banda horizontal.

Entre los escasos fragmentos que nos han permitido determinar la forma de las vasijas contamos con tres que corresponden a recipientes abiertos, ofreciendo formas de algo menos de tres cuartos de esfera (fig. 2: 32, 38 y 40). Presentan las mismas características no sólo en lo que a forma se refiere, sino también en la decoración, puesto que, además de la capa de almagra, muestran una asociación decorativa a base de impresiones circulares u ovales que se localizan en el labio o justamente debajo de éste, al tiempo que los diámetros, al menos en dos de ellas, ofrecen prácticamente la misma medida, 35 y $34,4 \mathrm{~cm}$., alcanzando el tercero $27,6 \mathrm{~cm}$.

A una forma de tres cuartos de esfera corresponde la $n^{\circ} 72$ (fig. 2), asociada a un asa acodada vertical. Su diámetro mide $11,8 \mathrm{~cm}$. Por último, contamos con una forma compuesta con cuello cuerpo globular (fig. 2: 17).

\section{Cerámica Acanalada}

Esta especie cerámica supone, con 7 fragmentos, el 6,08\% del total cerámico y el $6,54 \%$ del decorado (fig. 3: 53, 49, 87 y 77). Ofrecemos sus características generales atendiendo al número de fragmentos, no al valor porcentual. 


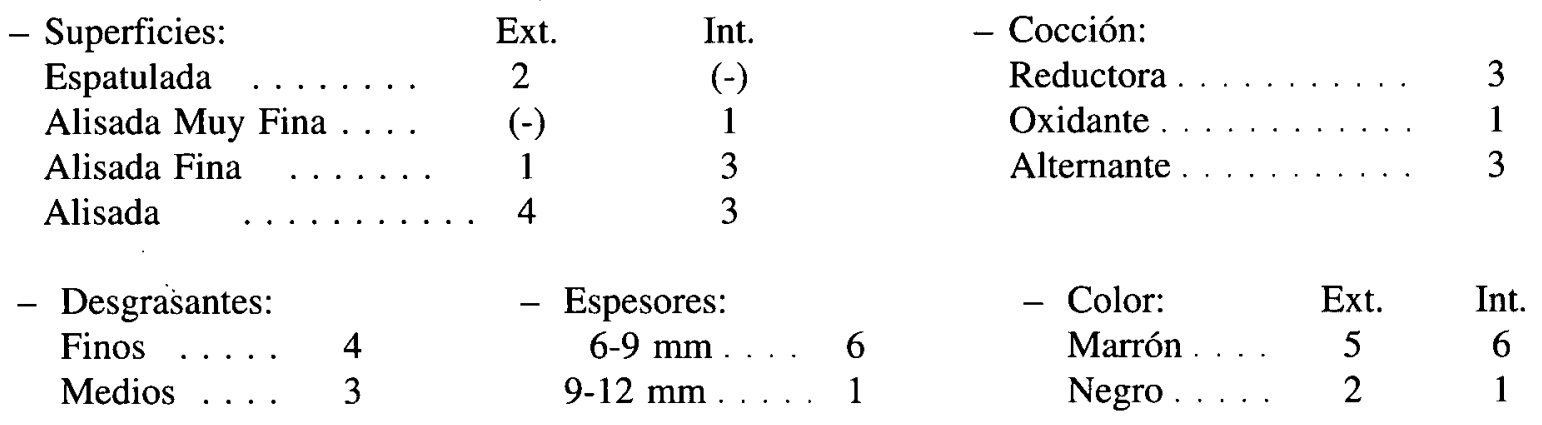

Por tipos de fragmentos, contamos con bordes, S.P.S. y atípicos. La dirección de los bordes es entrante en uno y saliente en otro, siendo la forma del labio redondeada en ambos (figs. 49 y 53). En ningún caso hemos podido determinar la medida de sus diámetros. Sólo contamos con un S.P.S., tratándose de un mamelón macizo de forma tendente a la orejeta.

El tamaño de las acanaladuras es medio (superior a $2,5 \mathrm{~mm}$.) y la presión es generalmente profunda. La temática se reparte entre bandas horizontales (en 3 casos), bandas quebradas, de tipo greca posiblemente ( 2 ejemplares), bandas o líneas verticales y ondas ( 1 caso cada uno). Finalmente, el fragmento $n^{\circ} 53$ (fig. 3) está asociado a un cordón vertical y sobreelevado, decorado mediante impresiones.

La alta fragmentación del material no nos ha permitido la reconstrucción de ninguna vasija.

\section{Cerámica Incisa}

Esta especie, con 6 fragmentos, representa el 5,21\% del total cerámico y el 5,60\% del decorado.

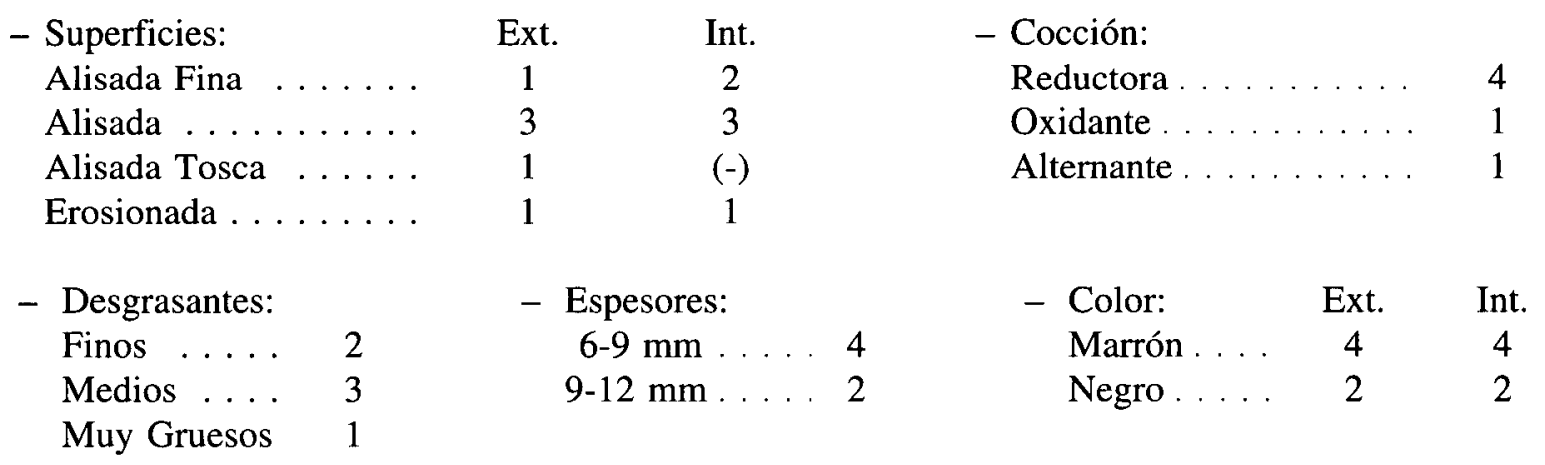

Por tipos de fragmentos, contamos con bordes, S.P.S. y atípicos. De los dos bordes con que contamos, la dirección en uno es ligeramente entrante y en el otro entrante; la forma del labio es en uno biselada y en el otro redondeada-apuntada. Sólo tenemos un S.P.S, un asa anular vertical que sobresale por encima del labio de la vasija.

En cuanto a la decoración, el tamaño de las incisiones es medio ( 3 ejemplares), fino y grueso (1 caso cada uno); la presión ejercida es media ( 2 fidgmentos), profunda (en 2) y, por último, suave (1 ejemplar); la temática, muy homogénea (fig. 3: $21,130,13$ y 80), se reparte entre grupos de líneas o bandas horizontales ( 4 ejemplares), ondas ( 1 caso) y líneas oblicuas ( 1 ejemplar). Tres de los fragmentos ofrecen una asociación decorativa a base de impresiones (fig. 3: 80, 13 y 21) siendo, en dos de los 
casos, circulares y se encuentran debajo de la banda de incisiones, mientras que en el que resta, las impresiones parten del labio de la vasija.

\section{Cerámica con Decoración Plástica Aplicada}

Abarca el 2,60\% del total de la cerámica y el 2,80\% del material decorado.

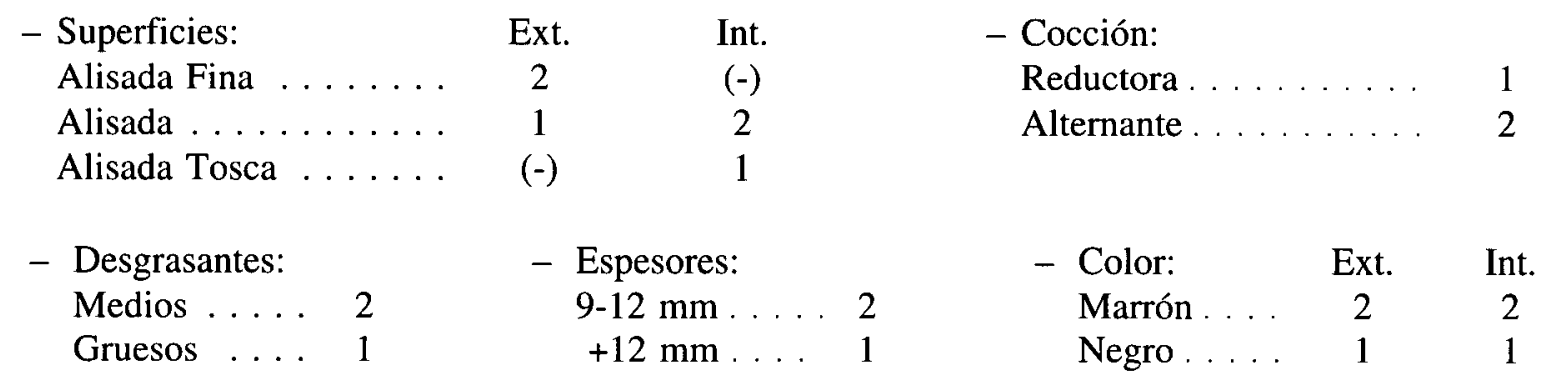

En cuanto a tipos de fragmentos, contamos con dos bordes y un atípico. Los bordes son, en un ejemplar, saliente y en el otro no determinable; las formas de labio presentes son la redondeada y la plana, estando el diámetro del ejemplar determinable entre $13-15 \mathrm{~cm}$. La decoración se ha efectuado invariablemente a base de la aplicación de cordones: en una ocasión liso vertical; otro de los fragmentos presenta dos cordones, impresos y posiblemente arqueados, que parten del arranque del S.P.S. (fig. 4: 51); el tercer fragmento ha sido decorado mediante cordón vertical inciso (fig. 4: 52).

Como ya queda comentado al tratar del análisis de la cerámica acanalada, contamos con un ejemplar en el que esta técnica decorativa se asocia a un cordón vertical impreso que sobrepasa el borde.

\section{Cerámica Impresa}

Los dos fragmentos con que contamos pertenecientes a esta especie suponen el IFm del total cerámico de este primer conjunto, tanto del material selecto $(1,73 \%)$ como del decorado $(1,86 \%)$.

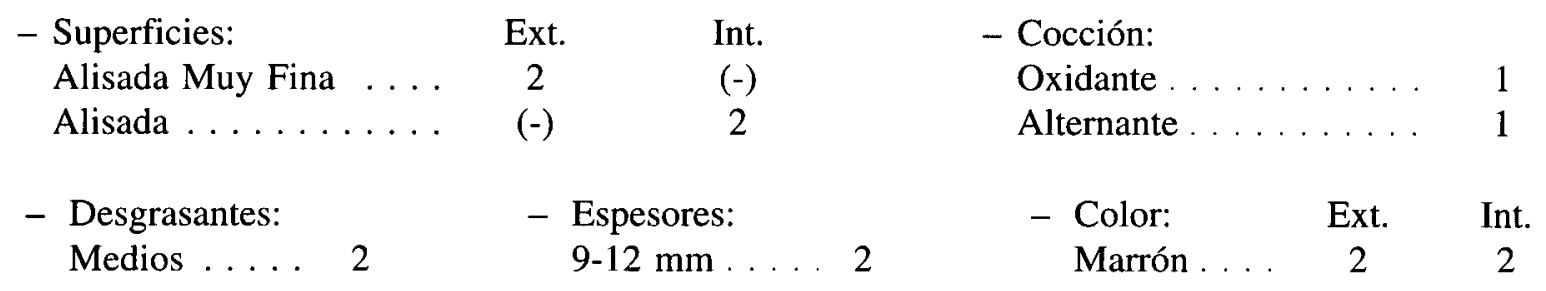

Por tipos de fragmentos, contamos con un borde y un atípico. El borde es de dirección saliente, la forma del labio es redondeada-apuntada y de $30,4 \mathrm{~cm}$. de diámetro máximo. Presenta una decoración en el borde, justamente debajo del labio, a base de impresiones ovaladas (fig. 3: 74).

Por su parte, el fragmento $\mathrm{n}^{\mathrm{o}} 1$ (fig. 3), muestra una decoración a base de círculos dispuestos en líneas horizontales que abarcan casi toda la superficie conservada. 


\section{Cerámica No Decorada}

Dentro de los fragmentos que, carentes de decoración, hemos adjudicado al Neolítico contamos con un total de 8 ejemplares, que abarcan el $6,95 \%$ del material selecto.

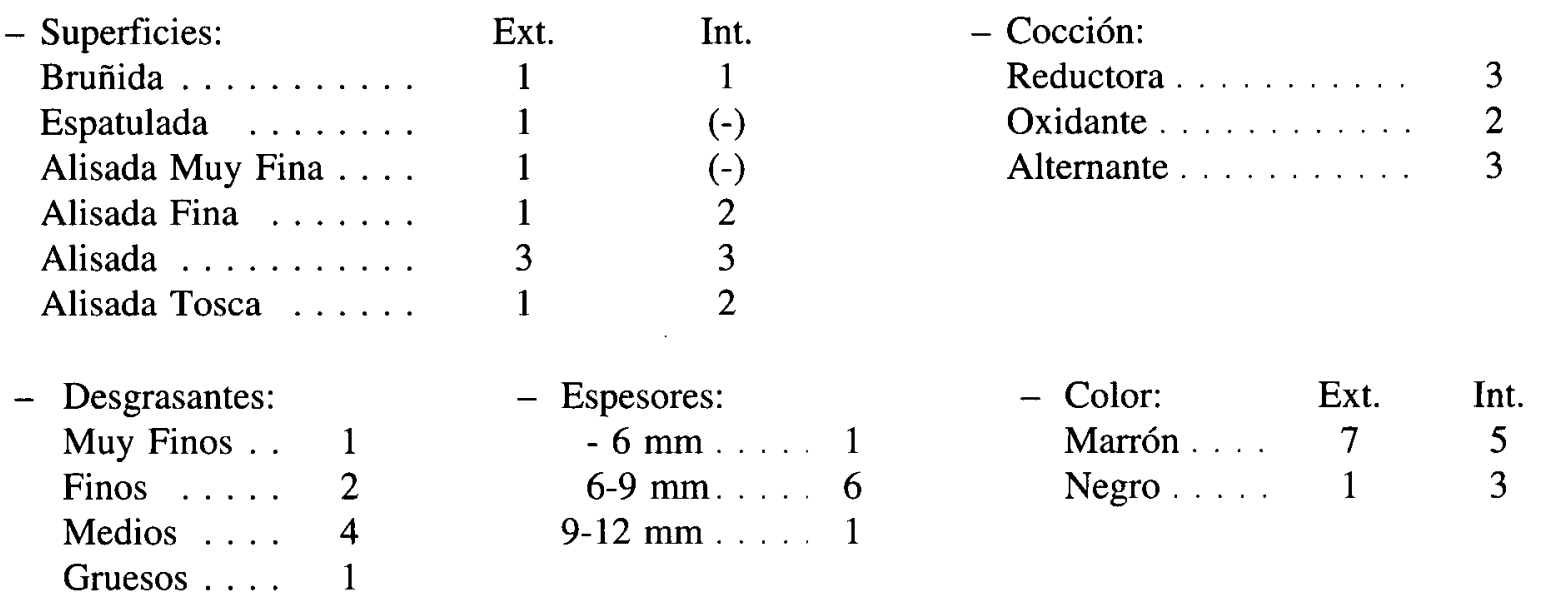

Por tipos de fragmentos, contamos con ocho bordes, alguno de ellos asociados a S.P.S. Los bordes son de dirección saliente en tres ejemplares, entrante en otros tantos, recto en uno y no determinable en el que resta.

La forma del labio es estrangulada en tres casos (fig. 4: 101, 16 y 15), redondeada en dos, indicada en dos y biselada en uno. Debido a la alta fragmentación del material y a las reducidas porciones que han llegado hasta nosotros, no hemos podido determinar los diámetros de ninguna de las vasijas pertenecientes a esta especie cerámica. Con respecto a los S.P.S, contamos con un mamelón elíptico aplastado sobreelevado en el borde (fig. 4: 76).

Globalmente, se trata de un conjunto cerámico bastante homogéneo que se caracteriza por el buen acabado de sus superficies, algo mejor tratadas al exterior que al interior, hecho al que responden la tónica general de los productos de alfarería pertenecientes al Neolítico.

En lo que se refiere a la adjudicación cultural de este primer conjunto cerámico, resulta factible proponer una adscripción neolítica basándonos en la semejanza que muestran sus características técnicas y decorativas con las presentes en numerosos yacimientos neolíticos, principalmente situados en cuevas, de la zona occidental andaluza.

Dado que sería demasiado prolijo citar todos los paralelos que se establecen entre decoraciones, formas cerámicas, tipos de S.P.S., etc., nos parece más aconsejable basarnos sólo en los más significativos y que aparecen en yacimientos no demasiado distantes, aunque, en ocasiones, acudamos a otros situados en zonas más alejadas, pero limitando siempre, y en la medida de lo posible, los paralelos.

Semejanza entre nuestros materiales y los procedentes de yacimientos en cueva con estratigrafía las observamos, entre otras, en la Cueva de La Dehesilla (Acosta y Pellicer 1990), donde se documentan formas abiertas, de un cuarto de esfera y con el labio decorado mediante impresiones, a partir del Neolítico Antiguo A, mostrando un marcado descenso tras éste, y que resultan semejantes a las $\mathbf{n}^{\circ} 40-41$, 74, 32 ó la 38-39 del yacimiento de Las Barrancas. En Lebrija (Caro y otros 1986), estos temas decorativos aparecen en Neolítico Medio/Final, y en Cueva Chica de Santiago en el Neolítico Final. 
Estamos, pues, ante temas que se inician a comienzos del Neolítico y perduran hasta los momentos finales de este período, siendo frecuentes en todo el ámbito occidental andaluz.

De igual modo, contamos con varios fragmentos que ofrecen una decoración a base de grecas, como las que se dan en Dehesilla en el Neolítico Antiguo, siendo frecuentes, también, en los niveles correspondientes a la primera ocupación neolítica de la Cueva de los Murciélagos de Zuheros, Neolítico A, (Gavilán y Vera 1992), según las últimas excavaciones efectuadas en este yacimiento.

Por su parte, los bordes estrangulados e indicados, 'si bien aparecen en Dehesilla ya en el Neolítico Medio (Acosta y Pellicer 1990), son más frecuentes en el Neolítico Final; en la Cueva de la Carigüela, los bordes estrangulados se documentan en los niveles IV, V y VI, siendo especialmente abundantes en el VI, y los indicados en los niveles III y VII. Navarrete (1976), aceptando en buena medida las fases propuestas por Pellicer (1964), indica que los niveles VIII a II pertenecen al entonces denominado Bronce I. Posteriormente, Pellicer lleva a cabo (en Jordá y otros 1986) una revisión de la estratigrafía de esta cavidad y reconsidera, oportunamente desde nuestro punto de vista, su adjudicación cultural, adscribiéndolos ahora los niveles VIII a V al Neolítico Reciente. Se trata, por tanto y a tenor de las estratigrafías, de un tipo de borde que, si bien se encuentra ya presente en el Neolítico Medio, es más usual en la fase Final del período, adjudicación ésta que nos parece más factible en el caso del yacimiento de Las Barrancas.

Mamelones aplanados, como el de la figura $4\left(n^{\circ} 76\right)$, se documentan en Dehesilla en el Neolítico Antiguo A (fig. 10: 15 ó 1311) (Acosta y Pellicer 1990), existiendo también ejemplares de este tipo en el Neolítico Antiguo de la Cueva Chica de Santiago. En cuanto a las asas acodadas, se constatan en Dehesilla en el Neolítico Antiguo y Medio y en Cueva Chica de Santiago en la fase antigua, entre otros yacimientos.

Así, pues, y teniendo presente estos paralelos, podemos adjudicar los materiales de Las Barrancas al Neolítico y, dentro de éste, nos inclinamos a favor de las fases correspondientes al Neolítico Medio y Final, inmerso en las características generales que este período presenta en Andalucía Occidental.

\section{- Cerámica adjudicable al Calcolítico y a la Edad del Bronce}

Como correspondiente a las etapas de la Metalurgia hemos incluido un volumen de restos que muestran unas características generales que difieren notablemente del anterior conjunto. No obstante, hemos de decir que no se nos escapa la dificultad que entraña el determinar si algunas cerámicas no decoradas pertenecen al Neolítico, Calcolítico o Edad del Bronce. De este modo, para ello, nos hemos atenido a las características de la pasta y su textura, teniendo también presente la forma en los casos en que ésta resulta reconstruible y/o determinable.

Por otra parte, y dado que son escasos los fragmentos cuya forma ha podido determinarse dentro de las cerámicas que hemos adjudicado a estos períodos de la Prehistoria, de modo que podamos realizar una separación entre las que posiblemente correspondan al Calcolítico y a la Edad del Bronce, hemos optado por ofrecer sus características generales de forma globalizada $\mathrm{y}$, más adelante, indicaremos aquellas cuyas características y tipología apunten más directamente hacia uno u otro período cronológico y cultural (fig. 5).

\section{Cerámica No Decorada}

Así, pues, este conjunto que vamos a analizar a continuación alcanza el 25,85\% del total del material cerámico y el $28,65 \%$ del material cerámico selecto. Los 47 fragmentos con que contamos ofrecen las siguientes características generales que plasmamos en cuadros: 


\begin{tabular}{|c|c|c|c|c|c|c|c|}
\hline \multicolumn{2}{|l|}{ - Superficies: } & Ext. & Int. & & - Cocción: & & \\
\hline \multicolumn{2}{|l|}{ Bruñida . . . } & $4,25 \%$ & $2,12 \%$ & & Reductora & & $23,40 \%$ \\
\hline \multicolumn{2}{|l|}{ Espatulada $\ldots$} & $2,12 \%$ & $(-)$ & & Oxidante. & & $21,27 \%$ \\
\hline \multicolumn{2}{|l|}{ Alisada Muy Fina } & $14,89 \%$ & $4,25 \%$ & & Nervios . . & & $2,12 \%$ \\
\hline \multicolumn{2}{|l|}{ Alisada Fina . . . } & $21,27 \%$ & $21,27 \%$ & & Alternante . & & $53,21 \%$ \\
\hline \multicolumn{2}{|l|}{ Alisada ... . } & $44,71 \%$ & $40,46 \%$ & & & & $100,00 \%$ \\
\hline \multicolumn{2}{|l|}{ Alisada Tosca } & $12,76 \%$ & $29,78 \%$ & & & & \\
\hline Muy Tosca . . & & $\frac{(-)}{10000 \%}$ & $\frac{2,12 \%}{10000 \%}$ & & & & \\
\hline - Desgrasantes: & \multicolumn{2}{|r|}{-} & Espesores: & & - Color: & Ext. & Int. \\
\hline Muy Finos . . & $12,76 \%$ & & $6-9 \mathrm{~mm}$ & $40,43 \%$ & Marrón & $74,47 \%$ & $80,86 \%$ \\
\hline Finos $\ldots$. & $23,53 \%$ & & $9-12 \mathrm{~mm}$ & $36,17 \%$ & Negro . & $25,53 \%$ & $19,14 \%$ \\
\hline Medios & $29,81 \%$ & & $+12 \mathrm{~mm}$. & $14,89 \%$ & & $100,00 \%$ & $100,00 \%$ \\
\hline Gruesos .... & $23,40 \%$ & & & $100,00 \%$ & & & \\
\hline Muy Gruesos & $\frac{6,38 \%}{100,00 \%}$ & & & & & & \\
\hline
\end{tabular}

Por tipos de fragmentos, contamos con bordes y con S.P.S. asociados a bordes.

\begin{tabular}{|c|c|}
\hline & \\
\hline Entrante $\ldots \ldots \ldots$ & $29,80 \%$ \\
\hline Recta . & $27,65 \%$ \\
\hline Saliente & $17,02 \%$ \\
\hline No determinable $\ldots$ & $\frac{25,53 \%}{100,00 \%}$ \\
\hline
\end{tabular}

- Forma de los labios

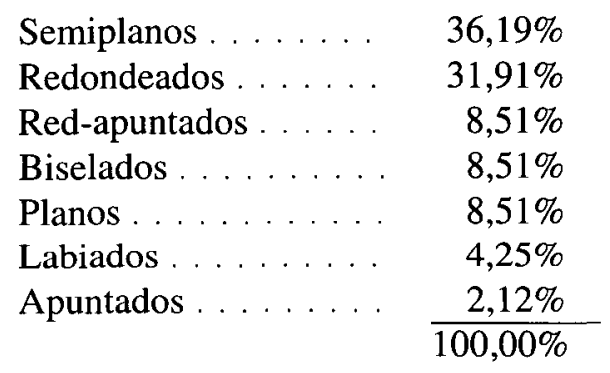

Escasos son los fragmentos que han resultado válidos para la determinación del diámetro. De hecho, sólo contamos con cinco casos, de los que en dos ejemplares las medidas están comprendidas entre los $11-13 \mathrm{~cm}$., en uno entre $9-11 \mathrm{~cm}$., en otro entre $17-19 \mathrm{~cm}$ y en el restante entre $223-25 \mathrm{~cm}$. Contando, pues, con un porcentaje nada desdeñable de diámetros no determinables $(89,39 \%)$. Por su parte, los S.P.S. son siempre a base de mamelones circulares (fig. 5: 50, 147 y 146), observándose en uno de ellos el inicio de una perforación (fig. 5: 88).

Como comentábamos al inicio del análisis cerámico, por las características, factura y forma de estos fragmentos, algunos de ellos podrían permitir, tal vez, una adjudicación cultural calcolítica. Sin embargo, estando ausentes las formas típicas o definitorias de las distintas fases de este período, resulta sumamente difícil hacer precisiones no ya cronológicas sino culturales, dado que las formas que proporcionan los fragmentos de borde -que, aunque no contemos en ningún caso con la cantidad suficiente que nos permita su reconstrucción, dejan entrever formas tendentes a tres cuartos de esfera, media esfera y un cuarto de esfera- no son ajenas a la Edad del Bronce.

En este sentido, no puede soslayarse, como manifiestan algunos autores que han analizado zonas próximas o colindantes (Amores 1982), la existencia de elementos arcaizantes de raigambre calcolítica 
presentes en yacimientos que cuentan con materiales más avanzados -ya dentro del Bronce Final- en los sectores central y occidental andaluces. Dado que los elementos cerámicos característicos y definitorios del Calcolítico, ausentes en el yacimiento que nos ocupa, están de sobra constatados en otros asentamientos cercanos, nos parece más acertado proponer una adjudicación cultural más tardía para estos materiales, pertenecientes, quizá, a ese momento correspondiente a la Edad del Bronce Pleno aún no bien caracterizado por la escasez de yacimientos claros y materiales definitorios, como viene siendo una constante en este sector y que, como comentamos más arriba, se podría caracterizar por la perduración de elementos de raíz calcolítica.

De otro lado, mayor precisión cultural pueden permitirnos determinados fragmentos, como el $\mathrm{n}^{\circ} 90$ (fig. 5), que podríamos adjudicar al Bronce Pleno, o los ejemplares $n^{\circ} 89$ y 141 (fig. 5), que nos remiten al Bronce Final Reciente.

\section{Cerámica Engobada}

Contamos únicamente con dos ejemplares:

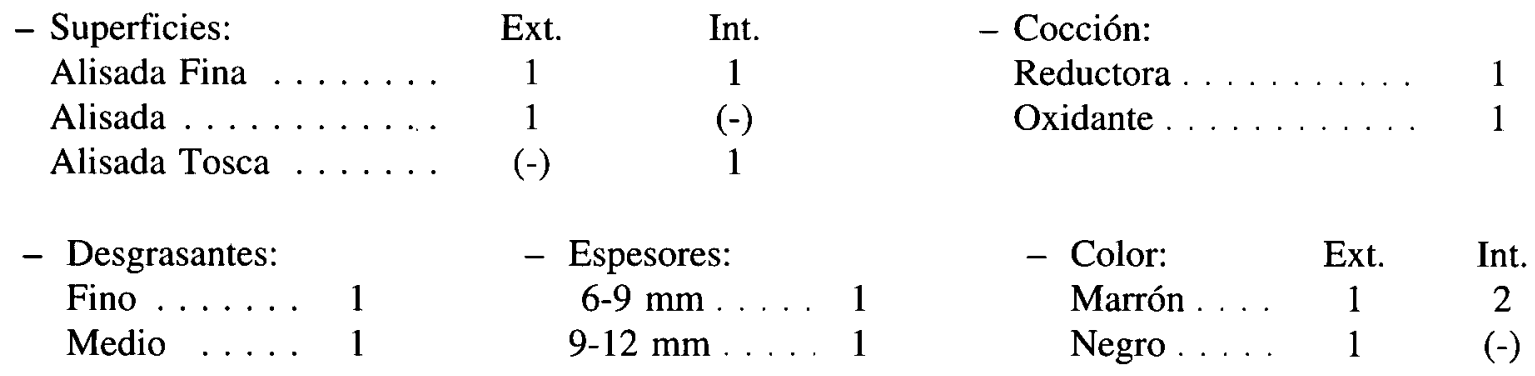

El engobe se presenta, en un caso, sólo al exterior y es de color gris, estando en el otro en ambas caras, que ofrece un engobe de color rojizo-anaranjado, siendo éste de tonalidad y textura diferente a las típicas almagras. En este caso, estamos ante una capa de almagra no sólo de escasa calidad -también frecuente entre las pertenecientes al Neolítico-, sino de una especie de aguada, de manera que participa de las características que esta especie cerámica ofrece ya en momentos pertenecientes a la Edad del Cobre, como consecuencia de las lógicas perduraciones materiales entre el Neolítico y el Calcolítico.

El hecho que nos impulsa a considerar una posible adjudicación calcolítica para estos dos fragmentos estriba en la relativa frecuencia con que aparecen las decoraciones mediante una especie de "engobe" en determinados yacimientos calcolíticos, siendo francamente inusuales en los neolíticos que, por otra parte, cuentan con la aplicación del característico engobe a la almagra, de amplio cromatismo.

Cerámicas con decoración mediante la aplicación de engobe se encuentran en numerosos yacimientos de este sector; entre los que, podemos citar el Rancho del Zurdo y Alcaudete, para los que se ha propuesto una adjudicación calcolítica, aunque contando algunos de ellos con elementos pertenecientes a etapas más avanzadas (Amores 1982).

\section{- Atípicos sin decorar}

Este conjunto de fragmentos supone, con un total de 19 fragmentos, el 10,38\% del total del material cerámico. Sus características generales son las siguientes: 


\begin{tabular}{|c|c|c|c|c|c|c|c|}
\hline \multicolumn{2}{|l|}{ - Superficies: } & Ext. & Int. & & - Cocción: & & \\
\hline \multicolumn{2}{|c|}{ Alisada Muy Fina . . . . } & 1 & 1 & & Reductora & $\ldots \ldots$ & 3 \\
\hline \multicolumn{2}{|c|}{ Alisada Fina $\ldots \ldots$} & 3 & 2 & & Oxidante . & & 6 \\
\hline \multicolumn{2}{|l|}{ Alisada . . . . } & 9 & 7 & & Nervio . & & 2 \\
\hline \multicolumn{2}{|l|}{ Alisada Tosca } & 6 & 6 & & Alternante . & $\ldots$ & 8 \\
\hline \multicolumn{2}{|l|}{ Tosca ..... } & $(-)$ & 3 & & & & \\
\hline \multicolumn{2}{|l|}{ - Desgrasantes: } & - & Espesores: & & - Color: & Ext. & Int \\
\hline Muy Finos . . & 1 & & $-6 \mathrm{~mm}$ & 3 & Marrón & 16 & 13 \\
\hline Finos $\ldots$. & 5 & & $6-9 \mathrm{~mm}$ & 8 & Negro & 3 & 6 \\
\hline Medios .... & 10 & & $9-12 \mathrm{~mm}$. & 7 & & & \\
\hline Gruesos . . . & 2 & & $+12 \mathrm{~mm}$ & 1 & & & \\
\hline Muy Gruesos & 1 & & & & & & \\
\hline
\end{tabular}

Para finalizar, merece la pena destacar la existencia de un fragmento atípico que presenta tres lados recortados.

Poco es lo que puede decirse acerca de la posible adjudicación cronológica y/o cultural de estos fragmentos dado su carácter, atípico, y, por lo tanto, carente de cualquier determinación en cuanto a su forma. Bien es cierto que, por las características técnicas que muestran -tanto en el tipo de pasta, desgrasantes $\mathrm{y}$, en general, su aspecto- la mayoría de ellos podrían apuntar hacia etapas avanzadas, ya dentro de la Edad del Cobre y la Edad del Bronce. Empero, no debemos olvidar la presencia de abundante material neolítico y el hecho de que, a veces, las cerámicas no decoradas pertenecientes a este período no presentan un acabado muy cuidadoso, a lo que hay que sumar el que estos fragmentos, como es lógico, pertenecen tanto a cerámicas no decoradas como a porciones carentes de decoración de vasijas decoradas. Así, pues, teniendo en cuenta estos condicionantes, podemos estar, como de hecho opinamos, ante fragmentos pertenecientes a distintos momentos del Neolítico y de las etapas de la Metalurgia en general, hecho que resulta lógico si tenemos en cuenta la presencia de fragmentos cerámicos de tipología y morfología atribuibles a los citados períodos.

\section{Consideraciones generales}

A tenor de lo expuesto más arriba al tratar de cada conjunto cerámico, los restos materiales aportados por este yacimiento muestran un inicio del hábitat a partir del Neolítico Medio que continua a lo largo del Neolítico Final. Por las cerámicas engobadas, extremadamente escasas, podríamos contar con la presencia de una ocupación calcolítica difícil de precisar; sin embargo, la ausencia de elementos característicos y definitorios del Calcolítico, presentes en otros yacimientos muy próximos, nos impulsan a contemplar la posibilidad, ya apuntada con anterioridad, de que estemos ante un asentamiento que cuenta con materiales de raigambre calcolítica pero pertenecientes a etapas más avanzadas, es decir, al Bronce Pleno, prolongándose la ocupación de este asentamiento hasta el Bronce Reciente.

En cuanto al material lítico, en conjunto no contamos con una industria lo suficientemente clara para apoyar una adscripción neolítica definitiva del yacimiento, estando presentes unos materiales que, por otra parte, abarcan un amplio espacio temporal, corroborando las anteriores propuestas de adjudicación cultural.

Sin embargo, no es esta continuidad/discontinuidad lo que nos interesa resaltar con respecto a este asentamiento, ni tampoco el que haya proporcionado restos materiales pertenecientes a etapas más 
avanzadas, sino el hecho de contar con una ocupación que arranca claramente desde el Neolítico Medio. Por el volumen de restos neolíticos, superior en número a los adjudicables a etapas posteriores (los neolíticos alcanzan el $62,85 \%$ del total cerámico), podemos pensar que no estamos ante un hábitat tipo campamento de paso entre las sierras gaditanas y Sierra Morena, sino que, seguramente, constituye un ejemplo claro y patente de una ocupación posiblemente estacional y continuada (presencia de materiales pertenecientes al Neolítico Final, como ya se ha indicado) en la Campiña, con una elección muy determinada del sitio.

A juzgar por la dispersión que mostraban los restos neolíticos, aunque repartidos por un área de unos $300 \mathrm{~m}^{2}$, la mayor concentración se detectó en un espacio mucho menor, unos $30 \mathrm{~m}^{2}$, suponemos la existencia de un asentamiento reducido situado sobre una meseta, a la que no alcanzan las inundaciones y con magnífica visibilidad, al borde del río Corbones, que constituye, ya desde el Paleolítico Medio, una vía natural de penetración desde el Surco Intrabético hasta las tierras del interior.

\section{LOS ÁLAMOS}

Este yacimiento, cuyas coordenadas son $447,8 / 316,9$, se encuentra dentro del conjunto de los Cerros de San Pedro, formando lo que Fernández Caro (1992: 52) ha denominado "subconjunto Sur", ubicándose el tercer yacimiento que analizamos en este trabajo, San Pedro, en el subconjunto Norte.

Parte de los restos que aquí presentamos fueron dados a conocer por Fernández Caro (ibidem), quien determinó la existencia de tres puntos en los que afloraban restos materiales de época prehistórica.

Los 534 objetos procedentes de este yacimiento se distribuyen entre:
A.- Industria lítica tallada $\ldots \ldots .190$
$35,92 \%$
B.- Piedra pulimentada ....... 1
$0,18 \%$
C.- Adorno .............. 2
$0,37 \%$
D.- Varios $\ldots \ldots \ldots \ldots \ldots \ldots$
$0,18 \%$

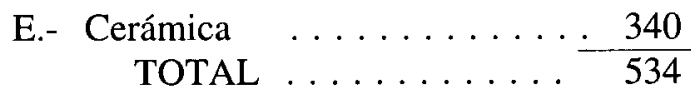
$63,69 \%$

\section{A.- Industria Lítica TaLlada}

Ya hemos comentado cómo el cuantioso volumen de industrias encontrado en este yacimiento ha sido dividido en dos conjuntos con base en dos criterios comúnmente utilizados en el estudio de industrias líticas: pátina y rodamiento. Pues bien, estos criterios se han visto reforzados por la homogeneidad tecnotipológica de ellos. Así, dos grupos líticos han podido establecerse en el conjunto de piezas recogidas en este yacimiento: uno formado por industrias con escaso rodamiento y pátina blanca, y otro con elementos de arsitas absolutamente frescas y colores originales. En el primero, las piezas se corresponden a modelos paleolíticos, y en el segundo, la tipología es encuadrable en momentos neolítico-calcolíticos. Este segundo conjunto va muy de acuerdo con los materiales cerámicos encontrados en el mismo contexto. También, aunque en menor grado, se ha detectado un buen número de útiles y restos de talla en cuarcita que presentan un grado de desgaste casi nulo y ausencia de pátina, y que han sido incluidos en el grupo paleolítico 
por la existencia de unos tipos y unas técnicas más cercanas al mundo mediopaleolítico de la zona, que conocemos por el trabajo de uno de los firmantes (Fernández Caro 1992), y porque su composición y dureza permite deteriorarse mucho menos que el sílex.

No obstante, también aquí es preciso recordar que nos hallamos ante un conjunto de industrias recogidas en superficie, donde, además, se ha utilizado dos tipos de materia prima: sílex y cuarcita, de las que, hasta el momento, poco conocemos sobre su comportamiento ante la acción de los agentes atmosféricos, de los agentes químicos modernos o de los incendios bianuales a los que se ven sometidos por su situación en campos de labor. De esta forma, es muy posible que algún producto de talla pueda presentar apariencia externa semejante a aquellos de un conjunto diferente al que cronológica o culturalmente le pertenezca, por lo que siempre hay que dejar un determinado margen de duda sobre la adscripción a uno u otro grupo.

En este trabajo, pues, procede el estudio del conjunto con características adecuadas al período neolítico-calcolítico que se pone de manifiesto en el capítulo de las cerámicas.

Las fuentes de aprovisionamiento debieron estar asociadas al mismo río Corbones. $\mathrm{O}$ bien, de las terrazas del río, donde puede encontrarse en forma de cantos de mediano tamaño (inferiores a $10 \mathrm{~cm}$. de diámetro), o bien de las mismas fuentes, en la zona de Villanueva de San Juan, donde las vetas son comunes. Igualmente, se ha comprobado la reutilización de material dadas las distintas pátinas que presentan algunas superficies de algunos materiales, especialmente núcleos.

El conjunto lo integran un total de 190 piezas $(35,58 \%$ del total), que se reparten del siguiente modo:

$$
\begin{array}{crrr}
\text { - Material Sin Retocar . . . . } & 101 & 53,15 \% \\
\text { - Material Retocado . . . . . } & 89 & 46,84 \% \\
\hline \text { TOTAL . . . . . . . . } & 190 & & 100,00 \%
\end{array}
$$

Estos conjuntos se distribuyen como sigue:

$\begin{array}{lcccc} & \text { Piezas } & \text { Mat. S/Ret. } & \text { Mat.Ret. } & \text { Total Ind. } \\ \text { - Núcleos . . . . } & 12 & 11,88 \% & (-) & 6,31 \% \\ \text { - Lascas . . . . } & 26 & 25,74 \% & (-) & 13,68 \% \\ \text { - Láminas . . . . } & 63 & 62,38 \% & (-) & 33,25 \% \\ \text { - Láminas . . . . } & 33 & (-) & 37,13 \% & 17,36 \% \\ \text { - Muescas . . . . } & 10 & (-) & 11,23 \% & 5,26 \% \\ \text { - Dientes de hoz . } & 21 & (-) & 23,59 \% & 11,05 \% \\ \text { - Perf./Taladro . . } & 4 & (-) & 4,49 \% & 2,10 \% \\ \text { - Truncaduras . . . } & 3 & (-) & 3,37 \% & 1,57 \% \\ \text { - Lám. b. abatido . } & 3 & (-) & 3,37 \% & 1,57 \% \\ \text { - Geométricos . . } & 1 & (-) & 1,12 \% & 0,52 \% \\ \text { - Raspadores . . . } & 2 & (-) & 2,24 \% & 1,05 \% \\ \text { - Buriles . . . . . } & 1 & (-) & 1,12 \% & 0,52 \% \\ \text { - Denticulados . . } & 2 & (-) & 2,24 \% & 1,05 \% \\ \text { - Raederas . . . . } & 3 & (-) & 3,37 \% & 1,57 \% \\ \text { - Cepillos . . . . } & 1 & (-) & 1,12 \% & 0,52 \% \\ \text { - Diversos . . . . } & 3 & (-) & 3,37 \% & 1,57 \% \\ \text { - Rotos . . . . } & 2 & (-) & 2,24 \% & 1,05 \% \\ \text { TOTAL . . . } & 190 & 100,00 \% & 100,00 \% & 100,00 \%\end{array}$




\section{- Material Sin Retocar}

- Núcleos: En total suman 12, de los que 4 presentan restos claros de haber usado como soportes de restos de talla (o útiles) de períodos anteriores. La mayoría presentan aspecto cúbico-poliédrico (encuadrables en los que se denominan núcleos globulosos), a excepción de uno, muy pequeño, de forma prismática, del que se han obtenido microlaminillas estrechas, y otro, también pequeño, de conformación levallois. Se trata de núcleos de pequeñas dimensiones para microlascas y microlascas anchas, que han utilizado las primeras huellas para nuevos planos de percusión, casi siempre de forma ortogonal.

- Lascas: Escasas, ascienden a 26, de las que 3 tiene aspecto levallois. Cinco son de semidescortezado y las demás internas. Sus talones con 4 corticales, 20 lisos, y dos aparecen abatidos.

- Láminas: Un total de 62 fragmentos y una lámina completa sin retocar han sido contabilizadas en este conjunto. De ellas, 37 poseen una sección trapezoidal y 26 triangular. Los talones correspondientes a los 19 fragmentos proximales detectados y la lámina completa son abatidos en 12 ocasiones, puntiformes en 5 , liso internos en 1 y facetado en 1.

Según sus anchuras se agrupan así:

$$
\begin{array}{rrrr}
5-9 \mathrm{~mm} .: & 17 & 10-14 \mathrm{~mm} .: & 34 \\
15-19 \mathrm{~mm} .: & 34 & 20-24 \mathrm{~mm} .: & 1
\end{array}
$$

\section{- Material Retocado}

- Láminas retocadas: Suman 33 fragmentos, de los que 12 son proximales, en los que reconocemos un talón liso, otro diedro y 10 abatidos.

Por su retoque comprobamos que hay 10 con retoque simple, 2 con retoque semiabrupto, 6 plano, 7 con microrretoques y 6 con retoque denticulado.

En cuanto a sus anchuras, en los 33 fragmentos podemos establecer los siguientes grupos:

$\begin{array}{rrrr}5-9 \text { mm.: } & 2 & 10-14 \text { mm.: } & 13 \\ 15-19 \text { mm.: } & 14 & 20-24 \text { mm.: } & 3 \\ 25-29 \text { mm.: } & 1 & & \end{array}$

Comprobamos que existe una correspondencia entre las láminas sin retoque y las que están retocadas en cuanto a las proporciones de los talones, donde predominan los abatidos, y en cuanto a las anchuras de las láminas, donde el grupo sobresaliente es el de 10-20 mm.

- Muescas: Hay 10, seis sobre fragmentos mediales, tres sobre fragmentos proximales y una sobre lasca. Las nueve primeras son retocadas, entre las que contamos con una doble muesca opuesta, y la última es simple. En cuanto a los talones, hay uno liso, uno facetado y dos abatidos. Son inversas cinco, directas cuatro y la doble, directo en una e inverso en la otra.

- Dientes de hoz: Suman 21 y entre ellos se pueden formar tres subconjuntos: El primero lo integrarían aquellas piezas elaboradas sobre lascas y láminas que poseen doble o única truncadura (el lado opuesto se corresponde con el talón del soporte al que no se ha retocado) y dorso retocado con retoque abrupto opuesto al filo con retoque denticulado, excepto uno que posee un retoque marginal discontinuo; el segundo grupo los formarían piezas elaboradas sobre láminas con doble o única truncadura, poseyendo los dos bordes o uno solo retocado mediante un retoque denticulado o simple continuo; y por último, un grupo de piezas, probablemente sobre lasca, ya 
que sólo en una podemos afirmarlo, con truncaduras rectas o cóncavas y dorsos mucho menores que sus filos. Del primer grupo contamos 11 elementos de los que 3 presentan "lustre de cereal" y uno presenta síntomas de calentamiento antes de su separación del núcleo; del segundo 6, de los que sólo uno posee el citado "lustre de cereal", y del tercero contabilizamos 4 piezas. De los cinco talones reconocibles, tres son lisos y dos corticales.

Aplicando el sistema analítico de J. Ramos (1988-89), comprobamos que hay 14 con un borde denticulado, bien con retoque simple o microrretoque; 13 tienen el borde con retoque bifacial (incluidos aquellos con dos bordes denticulados en el que sólo presentan uno de ellos con el retoque bifacial requerido) y 8 unifacial; 16 poseen el dorso abatido y 5 no poseen dorso; 12 tienen el dorso tallado completo y 4 parcialmente; y por último, 13 presentan truncaduras en ambos extremos (incluida una lámina que sólo posee algunos retoques en las fracturas que componen sus extremos), 5 una sola truncadura, 1 ninguna, y dos presentan uno de los extremos rotos.

- Perforadores-taladro: Contamos con 4 perforadores, de los que 1 es atípico. Todos han sido realizados sobre fragmentos de láminas, uno distal, otro proximal, con talón liso, y los otros dos mediales, teniendo uno la base fracturada y el otro con fractura retocada. Los típicos presentan retoque abrupto, en uno de los cuales el retoque afecta a ambos bordes en su totalidad.

- Truncaduras: Hay 3, dos sobre lámina, de talones abatidos, y una sobre lasca, de talón liso. Una de las primeas es cóncava en extremo y sus lados también están retocados. La otra es recta oblicua sobre fragmento de lámina cuya fractura presenta retoque. La truncadura se consiguió mediante un retoque semiabrupto. La otra truncadura se realizó sobre lasca interna.

- Láminas de borde abatido: Contamos con 3, de las que dos son microlaminillas, y la tercera, fracturada, debió serlo también. Una de ellas presenta un microrretoque en el borde opuesto al dorso.

- Geométricos: Sólo se ha localizado un ejemplar. Tiene forma trapezoidal, teniendo en sus extremos un retoque abrupto. Su lado mayor mide $18 \mathrm{~mm}$. y el menor $6 \mathrm{~mm}$.

- Raspadores: Se contabilizan 2, laterales cortos; uno levemente destacado y el otro doble. Los dos han sido elaborados sobre lascas anchas, presentando uno retoque inverso. Uno posee talón cortical y el otro liso interno.

- Buriles: Hay 1, sobre plano con un solo paño. Se ha utilizado como soporte una lámina con talón suprimido y posee en el lado opuesto un retoque marginal de microdenticulado.

- Denticulados: Se han encontrado 2, y están realizados sobre pequeñas lascas. Una de ellas posee retoque simple y la otra marginal directo. El denticulado lo forman pequeñas muescas retocadas. Sólo uno posee talón, y es liso interno.

- Raederas: Se contabilizan 3, de las que dos son simples rectas y la tercera doble recta, y todas poseen retoque simple. Una de las simples está realizada sobre lasca levallois atípica con talón liso. La otra presenta el frente de raedera interrumpido por una amplia muesca en uno de sus extremos. La doble tiene talón liso, y mientras en uno de sus lados la zona retocada cubre todo el borde, en el otro sólo ocupa algo más de la mitad.

- Cepillos: Hay 1, realizado sobre un núcleo que utilizó como soporte un producto de talla anterior (reutilización). presenta huellas de extracciones de microlaminillas estrechas en el plano de deslizamiento y su frente está bien indicado mediante retoques simples sobreelevados.

- Diversos: Contamos con 3 piezas. Un frente de raspador, posiblemente sobre lámina, cuya fractura se halla retocada. El frente está retocado mediante retoque abrupto oblicuo al eje técnico de la pieza. Un astillado sobre un fragmento de lámina, presentando ambos extremos astillados, uno bifacialmente. Y, por último, una lámina que presenta el talón suprimido y una muesca laterobasal retocada a modo de pedúnculo. 
- Rotos: 2 piezas. Una podría tratarse de una pieza de hoz, ya que presenta un filo retocado del que destaca un bec opuesto a un dorso natural excepto la parte fracturada que parece tener una extracción abrupta a modo de dorso. La otra pieza rota es una lasca de semidescortezado en uno de cuyos bordes hay un retoque simple continuo, por lo que podría tratarse de una raedera simple lateral. Posee talón liso.

Del análisis efectuado comprobamos que nos hallamos ante una industria donde sobresale el elemento laminar, con predominio de las láminas anchas (10-20 mm.), de equilibrio entre talones lisos y abatidos (30 talones abatidos, 34 lisos, 2 facetados, 7 corticales, 1 diedro y 5 puntiformes).

Hay pocos núcleos, y los existentes son de pequeñas dimensiones, siendo importante que la tercera parte de ellos procedía de reutilizaciones de industrias antiguas (presumiblemente paleolíticas). Esto, unido a la escasez de lascas corticales y de semidescortezado, nos aleja de la posibilidad de encontrarnos ante un taller. Por otro lado, también es notorio que no hayamos encontrado ningún núcleo que mostrase huellas de extracciones de las láminas controladas.

En cuanto a las piezas tipológicas, se trata de una industria con débil presencia de la técnica levallois, abundancia de láminas con retoque continuo, donde abundan las de tipo evolucionado, significativo número de muescas, gran representación de dientes de hoz y testimonial de cepillos, y presencia moderada de sustrato Paleolítico (raspadores, buriles, perforadores y raederas) y del Epipaleolítico (laminillas de borde abatido y geométricos).

Así, pues, nos encontramos ante un conjunto lítico perfectamente compatible con el conjunto cerámico del yacimiento. Por un lado contamos con elementos que podrían adscribirse al Neolítico de las cerámicas acanaladas y a la almagra, laminillas de dorso abatido y geométricos, acompañados de buriles, raspadores, raederas, muescas, denticulados y algún que otro taladro, útiles éstos que si bien son más usuales en etapas inmediatamente anteriores, en algunas ocasiones pueden documentarse en contextos neolíticos; y por otro, un volumen de restos propios de una etapa posterior, como los dientes de hoz, los fragmentos de láminas anchas, un cepillo, perforadores-taladros,... que deben insertarse en los inicios del Calcolítico.

\section{B.- Piedra Pulimentada}

Dentro de este capítulo $(0,18 \%$ del total de los conjuntos) contamos con un fragmento distal de hacha (fig. 8: 1010); está bien pulimentada y ofrece una sección elíptica. Mide $6 \mathrm{~cm}$. de longitud, 2,9 cm. de anchura y $2 \mathrm{~cm}$. de grosor.

\section{C.- Adorno}

Sólo ha llegado hasta nosotros un colgante obtenido sobre un caracol y un fragmento de brazalete. El primero de ellos, de procedencia posiblemente marina, presenta una perforación y restos de pulimento. La segunda pieza está fabricada sobre calcita.

\section{D.- VARIOS}

En este apartado hemos incluido un fragmento de cuarzo que cuenta con dos extracciones. Mide $22,5 \mathrm{~mm}$. de longitud por $8,5 \mathrm{~mm}$. de anchura. Supone el $0,18 \%$ del material de este yacimiento. 


\section{E.- Cerámica}

El siguiente conjunto que analizamos procedente de este yacimiento lo integran un total de 340 piezas $(63,69 \%$ del total), parte de las cuales fueron dadas a conocer por uno de nosotros (Fernández Caro 1992). Como en el caso anterior, también este yacimiento ha proporcionado conjuntos industriales de diferente tipología y adjudicación cronológica y cultural distinta, de manera que los analizaremos separadamente, aunque, como resulta lógico al tratarse de materiales de superficie, hayamos tenido cierta dificultad con determinados items a la hora de incluirlos en un período determinado, como ocurre con algunos fragmentos de cerámica a la almagra, cuyas características están más en consonancia con las que se presentan en el Calcolítico que en el Neolítico.

El grueso del material procedente de este yacimiento corresponde al Calcolítico y a la Edad del Bronce que, con un total de 155 fragmentos cerámicos, alcanza un valor porcentual bastante elevado, 45,60\%. Por su parte, los restos adjudicables al Neolítico, con sólo 36 piezas, suponen únicamente el 10,88\%, corriendo a cargo de los fragmentos atípicos sin decorar el $43,52 \%$ que resta.

\section{- Cerámica adjudicable al Neolítico}

A este período corresponden la mayoría de los fragmentos pertenecientes a cerámica decorada, que contabilizan un total de 36, constituyendo el 10,88\% del total cerámico y el 19,27\% del material cerámico selecto. Contamos con las siguientes especies cerámicas:

$\begin{array}{cr}\text { - Almagra . . . . } & 23 \\ \text { - Acanalada . . . } & 4 \\ \text { - D.P.A . . . . . } & 4 \\ \text { - Incisa . . . . . } & 3 \\ \text { - Impresa . . . } & 3 \\ \text { TOTAL . . } & 37\end{array}$

\begin{tabular}{cr} 
fragmentos & $62,18 \%$ \\
$"$ & $10,81 \%$ \\
$"$ & $10,81 \%$ \\
$"$ & $8,10 \%$ \\
& $8,10 \%$ \\
\hline
\end{tabular}

Dada la escasez de los restos atribuibles al Neolítico que proceden de este yacimiento, no hemos creído conveniente emplear la estadística para su análisis, ofreciendo globalizadamente sus características generales.

\section{Cerámica a la Almagra}

Es la especie más abundante de este primer conjunto.

\begin{tabular}{|c|c|c|c|c|c|c|c|}
\hline & Ext. & Int. & & Cocción: & & \\
\hline \multicolumn{2}{|l|}{$\begin{array}{c}\text { - Superficies: } \\
\text { Bruñida . . . }\end{array}$} & 1 & $(-)$ & & Reductora . & . & 12 \\
\hline \multicolumn{2}{|l|}{ Alisada Muy Fina } & 3 & $(-)$ & & Oxidante . & 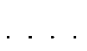 & 2 \\
\hline \multicolumn{2}{|l|}{ Alisada Fina $\ldots$} & 7 & 6 & & Nervio & . . & 6 \\
\hline \multicolumn{2}{|c|}{ Alisada $\ldots \ldots \ldots$} & 12 & 13 & & Alternante . & & 3 \\
\hline \multicolumn{2}{|l|}{ Alisada Tosca. } & $(-)$ & 3 & & & & \\
\hline \multicolumn{2}{|l|}{ Erosionada. . } & $(-)$ & 1 & & & & \\
\hline \multicolumn{2}{|l|}{ - Desgrasantes: } & & Espesores: & & - Color: & Ext. & Int. \\
\hline Muy Finos . . & 6 & & $-6 \mathrm{~mm}$ & 2 & Marrón & 18 & 15 \\
\hline Finos $\ldots \ldots$ & 6 & & $6-9 \mathrm{~mm}$ & 11 & Negro & 5 & 8 \\
\hline Medios .... & 11 & & $9-12 \mathrm{~mm}$ & 8 & & & \\
\hline
\end{tabular}




$\begin{array}{crr}\text { - Pigmento: } & \text { Ext. } & \text { Int. } \\ \text { Bermellón } \ldots \ldots \ldots & 14 & 9 \\ \text { Anaranjado } \ldots \ldots \ldots & 9 & 4\end{array}$

- Localización:

Exterior .......... 10

Interior $\ldots \ldots \ldots+(-)$

Ambas $\ldots \ldots \ldots, 13$

- Tipos de fragmentos:

Bordes .............. 5

Arranque de cuello y galbo ....... 1

Carenas ................. 1

Arranques de S.P.S . . . . . . . . 1

Atípicos ............. 15

Por su parte, los tipos de labios presentes corresponden todos a la forma redondeada, no habiendo sido posible determinar en ningún caso ni la dirección ni el diámetro debido a la alta fragmentación del material.

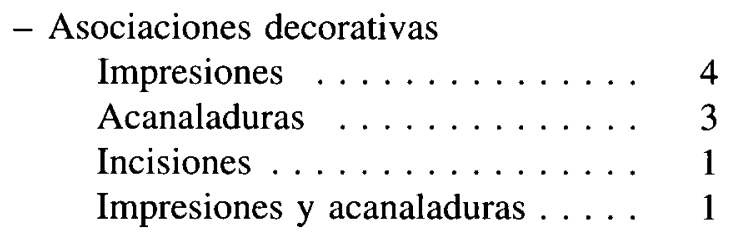

Los temas impresos asociados a la almagra describen en tres ocasiones motivos circulares que se localizan, en un caso, debajo del labio, tanto al exterior como al interior (fig. 7: 514), en otro en la línea de carenación de la vasija, y en el que resta en el galbo, siendo todos de tamaño medio y presión profunda. El cuarto ejemplar asociado a impresiones consiste en "uñadas" (fig. 7: 1001), de tamaño ancho y presión profunda.

Las acanaladuras desarrollan líneas horizontales de tamaño medio y presión profunda y suave, así como posibles ángulos en serie, de tamaño medio y presión suave. La asociación decorativa a base de incisiones consiste en líneas horizontales situadas debajo del borde, de tamaño y presión medios. Finalmente, destacamos la asociación decorativa a base de impresiones y acanaladuras que muestra el fragmento $\mathrm{n}^{\mathrm{o}} 1000$ (fig. 7), semejando las impresiones la impronta de granos de cereal.

\section{Cerámica Acanalada}

Esta especie la integran cuatro fragmentos que se reparten entre un borde y tres atípicos.

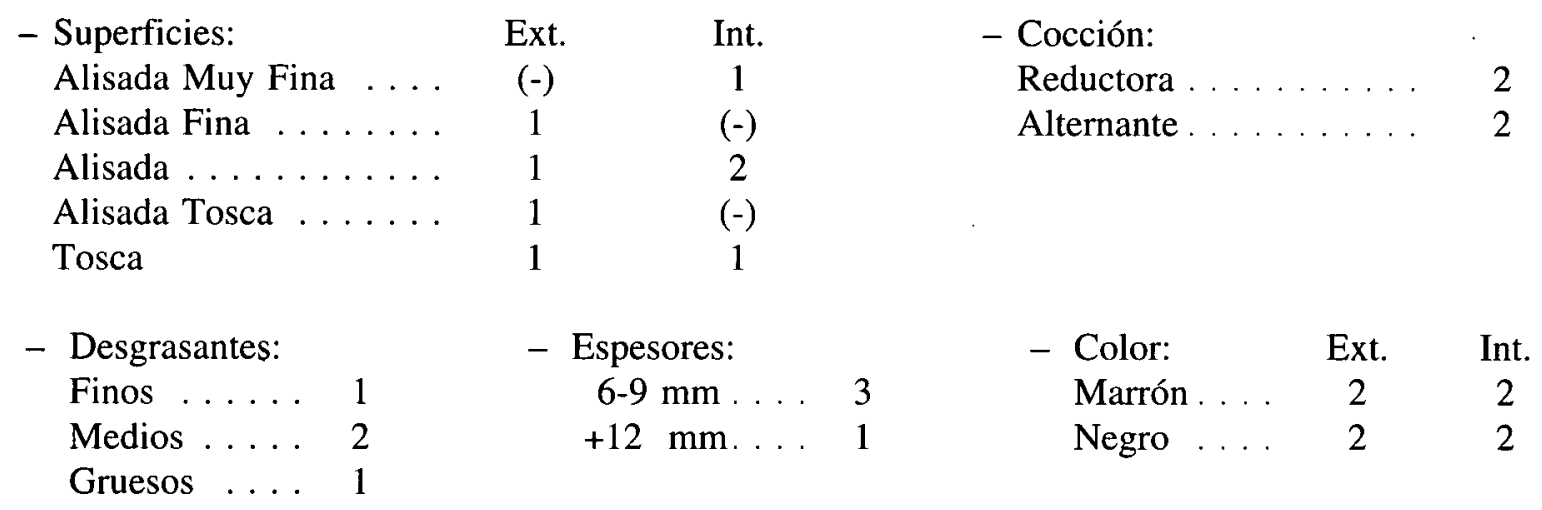


La temática presenta, en un caso, acanaladuras que parten directamente del labio, de tamaño ancho y presión suave, que presentan restos de pintura roja, de tonalidad bermellón (fig. 7: 503).

En dos fragmentos la decoración consiste en acanaladuras horizontales de tamaño fino y presión media. En otro ejemplar, las acanaladuras, de tamaño medio y presión profunda, parecen formar ángulos en serie.

Cerámica con Decoración Plástica Aplicada

Contamos con cuatro fragmentos que se reparten entre un borde y tres atípicos.

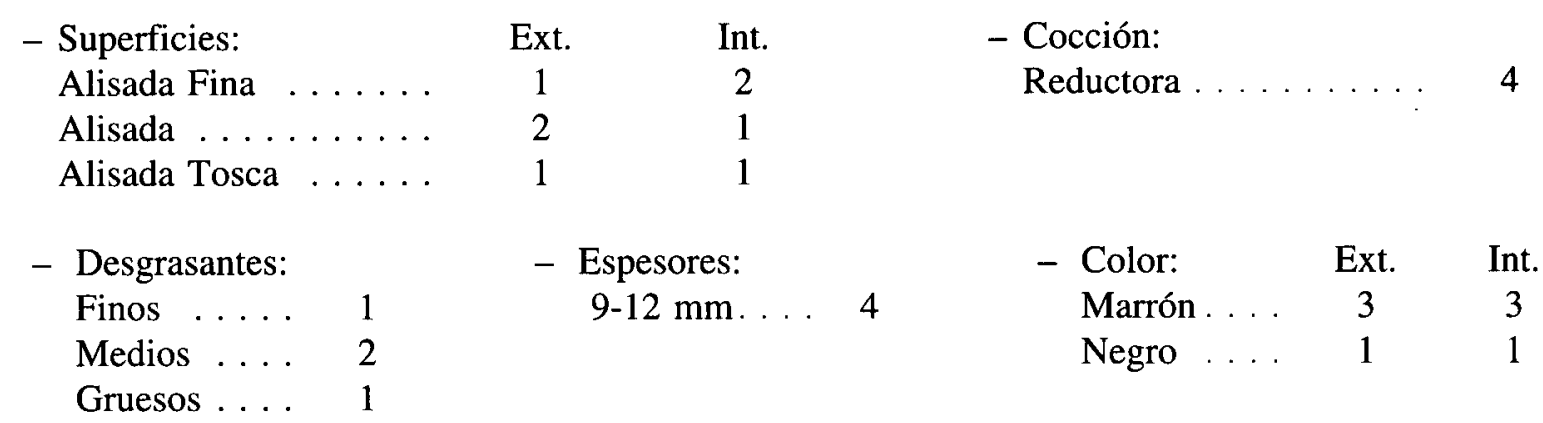

La decoraciones consisten en la aplicación de cordones, siendo en un caso oblicuo y liso, que parte directamente del labio, y horizontal en tres, mostrando una decoración a base de impresiones e incisiones (fig. 7: 501).

\section{Cerámica Incisa}

Los 3 fragmentos pertenecientes a esta especie cerámica se reparten entre un arranque de S.P.S y dos atípicos.

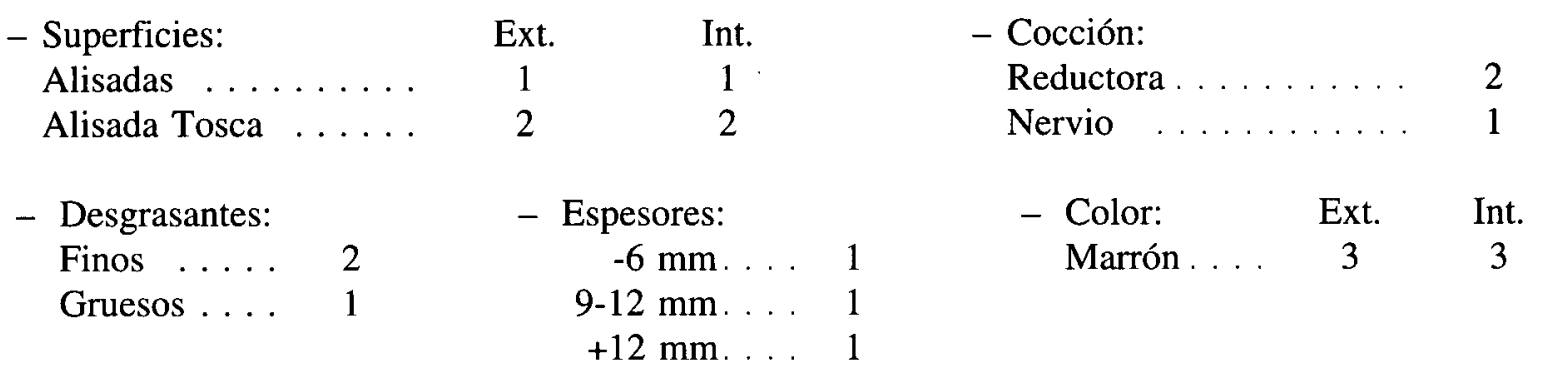

La decoración consiste en líneas horizontales en dos fragmentos (fig. 7: 1002) y en líneas oblicuas enmarcadas por líneas verticales en el tercero.

\section{Cerámica Impresa}

Los 3 fragmentos pertenecen a atípicos, uno de ellos decorado mediante cardium.

$\begin{array}{lcc}\text { - Superficies: } & \text { Ext. } & \text { Int. } \\ \text { Alisada Muy Fina . . . } & 1 & (-) \\ \text { Alisada Fina } \ldots \ldots \ldots & 1 & (-) \\ \text { Alisada } \ldots \ldots \ldots \ldots & (-) & 2 \\ \text { Alisada Tosca } \ldots \ldots \ldots & 1 & 1\end{array}$

- Cocción:
Reductora $\ldots \ldots \ldots \ldots$


- Desgrasantes: Finos ..... 3
- Espesores: 6-9 $\mathrm{mm} \ldots 3$

$\begin{array}{ccc}\text { - Color: } & \text { Ext. } & \text { Int. } \\ \text { Marrón . . . . } & 2 & 2 \\ \text { Negro _. . . } & 1 & 1\end{array}$

La decoración consiste en impresiones circulares en dos ejemplares, siendo el tamaño pequeño y la presión media en uno y ancho y medio en el otro (fig. 7: 512).

El tercer ejemplar (fig. 7: s/n) presenta una decoración, realizada mediante el borde dentado del cardium, que consta de una banda de impresiones oblicuas rematadas por una línea horizontal impresa, igualmente cardial.

Aunque escasos, la mayoría de los restos cerámicos que acabamos de describir nos parecen perfectamente adjudicables al Neolítico, con presencia de las especies básicas y usuales de este período; no obstante, no descartamos la posibilidad de que algunos de los fragmentos a la almagra pertenezcan a una etapa inmediatamente posterior, si nos dejamos llevar por la escasa calidad que muestra la capa de pigmento, así como por las características de la pasta, más en relación con las que aparecen a lo largo de las fases Inicial y Plena del Calcolítico que las del Neolítico, de factura más cuidada.

En lo que se refiere a la adjudicación cultural de la globalidad de los restos que acabamos de analizar, no nos parece necesario repetir para este yacimiento los paralelos ya establecidos para el anterior, puesto que presentan unas características muy semejantes, apreciándose, de hecho, una gran homogeneidad temática entre ambos, de manera que, basándonos en los anteriores paralelos citados, proponemos una adjudicación cultural comprendida entre el Neolítico Medio y el Final, más en consonancia con el Neolítico Andaluz Occidental que con el Oriental.

Una cuestión diferente nos plantea la presencia de cerámica impresa cardial que, aunque no resulta ser frecuente, por el momento, en Andalucía Occidental, no está ausente de los conjuntos cerámicos de determinados asentamientos, como es el caso de El Cabezo de Lebrija, donde aparece en los niveles 34 a 32, del Estrato I, adscritos al Neolítico Medio y Final (Caro y otros 1986), en el "Neolítico inicial" de Parralejo (Pellicer y Acosta 1982), estando ausentes en Dehesilla, donde sí se documentan, desde el Neolítico Antiguo A al Neolítico Medio B, las cardialoides (Acosta y Pellicer 1990).

Problemática resulta la adjudicación al Neolítico Antiguo de las cardiales detectadas en la Plaza de Mondragón de Ronda al tratarse de materiales que no se encontraban in situ, procediendo de zonas más elevadas (Aguayo y otros 1988).

Teniendo en cuenta, pues, que son escasas las cerámicas cardiales contextualizadas en Andalucía Occidental y que en algunos yacimientos aparecen en el Neolítico Antiguo y en otros en la fase Media, no podemos, en este caso, abogar claramente por una adjudicación del Neolítico Antiguo para el fragmento procedente de Los Alamos, sobre todo teniendo en cuenta que sólo contamos con un fragmento de esta especie, frente a un número más elevado de otros sistemas decorativos. Ante estas circunstancias, podemos considerar la posibilidad de que este yacimiento inicie una ocupación neolítica en los momentos finales de la fase antigua, o lo haga en un momento del Neolítico Medio, supuestamente en sus comienzos, teniendo en cuenta la unicidad del testimonio y la generalización de los modelos decorativos característicos del Neolítico Medio.

\section{- Cerámica adjudicable al Calcolítico y a la Edad del Bronce}

Contamos con un total de 155 fragmentos que abarcan el 45,60\% del total cerámico y el $80,73 \%$ del selecto, distribuyéndose de la siguiente manera: 


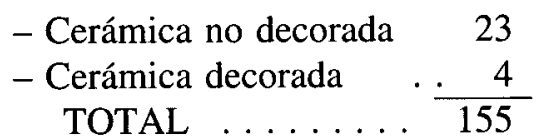

\begin{tabular}{cr} 
fragmentos & $98,71 \%$ \\
& $1,29 \%$ \\
\hline $100,00 \%$
\end{tabular}

\section{Cerámica No Decorada}

Con el $98,71 \%$, ofrece las siguientes características generales:

\begin{tabular}{|c|c|c|}
\hline - Superficies: & Ext. & Int. \\
\hline Bruñida . . . & $1,30 \%$ & $(-)$ \\
\hline Espatulada $\ldots . .$. & $(-)$ & $0,65 \%$ \\
\hline Alisada Muy Fina . . . . & $3,26 \%$ & $2,61 \%$ \\
\hline Alisada Fina $\ldots \ldots$ & $18,95 \%$ & $11,76 \%$ \\
\hline Alisada . . . . . . & $40,56 \%$ & $37,28 \%$ \\
\hline Alisada Tosca . & $28,75 \%$ & $35,29 \%$ \\
\hline Tosca ..... & $5,22 \%$ & $11,11 \%$ \\
\hline Muy Tosca & $1,96 \%$ & $0,65 \%$ \\
\hline \multirow[t]{2}{*}{ Erosionada } & $(-)$ & $0,65 \%$ \\
\hline & $100,00 \%$ & $100,00 \%$ \\
\hline
\end{tabular}

- Cocción:

Reductora . . . . . . 39,88\%

Oxidante . . . . . . . 25,49\%

Nervios . . . . . . . $8,49 \%$

Alternante . . . . . . 26,14\%

$100,00 \%$

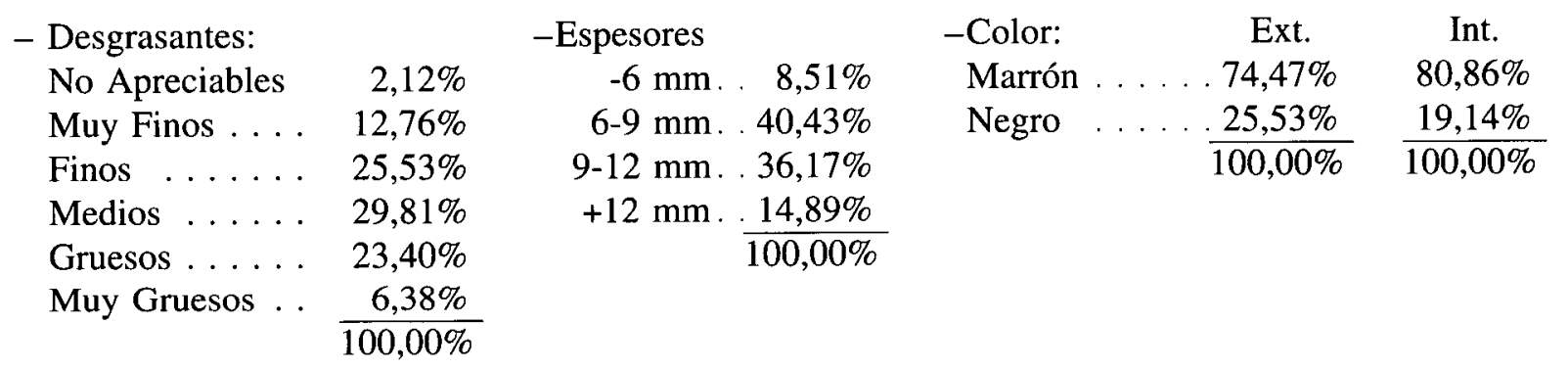

- Tipos de fragmentos:

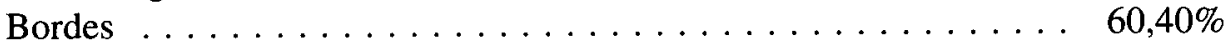

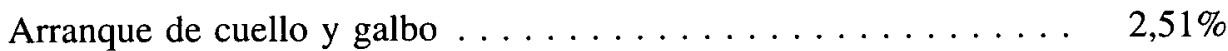

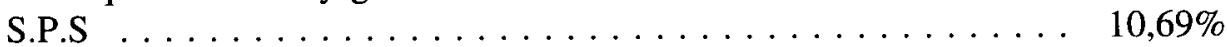

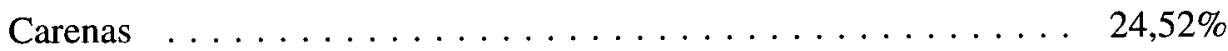

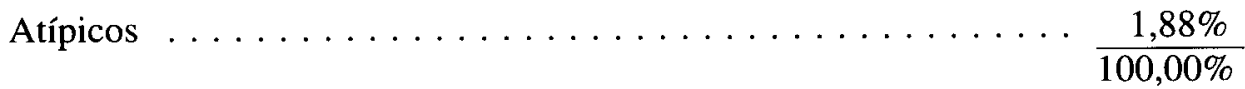

- Bordes:

Entrantes . . . . 21,87\%

Salientes ...... 15,62\%

Rectos ...... 9, $9,37 \%$

No determinables . $\frac{53,14 \%}{100,00 \%}$
- Forma de los labios:

Redondeados

$33,36 \%$

Semiplanos

$23,95 \%$

Planos

$17,70 \%$

Redondeados-apuntados

$15,62 \%$

Biselados . . . . . . . . . . 6, 6, 25\%

Indicado

$\frac{3,12 \%}{100,00 \%}$ 
Debido a la alta fragmentación del material, sólo en dos ocasiones hemos podido determinar la medida de los diámetros, que oscilan en un caso entre los $19-21 \mathrm{~cm}$. y en el otro entre $\operatorname{los} 21-23 \mathrm{~cm}$. En dos ocasiones se ha detectado la presencia de lañas en sendos fragmentos de borde.

Los S.P.S., escasos, se reparten entre cuatro fragmentos de asas de cinta, otros tantos arranques sin determinar, ocho mamelones (tres elípticos macizos, tres redondeados macizos y dos cónicos macizos), finalmente, contamos con un asa acodada de factura bastante tosca.

En cuanto a las carenas, hemos de decir que la gran mayoría pertenecen a cazuelas carenadas (fig. 8: 523 y 1003), presentando algunas de ellas el borde y estando una asociada a un mamelón elíptico macizo, siendo éstas casi las únicas formas con que contamos.

Finalmente, de las tres bases recogidas, dos de ellas son planas y la tercera semiplana.

En lo que se refiere a la adjudicación cultural de este segundo conjunto de materiales, somos de la opinión de que la abundancia de cazuelas carenadas nos permiten la propuesta de una adscripción al Calcolítico Inicial, pareciéndonos innecesario el acudir a los paralelos para apoyar esta adjudicación, dado que dichas formas resultan ser el denominador común de la fase inicial del Calcolítico, encontrándose en numerosos yacimientos al aire libre situados en zonas llanas y más o menos próximas a la nuestra, como es el caso de Papa Uvas en su Fase II (Martín de la Cruz 1994)

La ausencia de platos de borde engrosado, entre los materiales que hemos analizado, nos induce a considerar un abandono a comienzos de la fase media del Calcolítico; de otro lado, tampoco se ha documentado, hasta el momento, la presencia de campaniforme. Por último, contamos con algunos fragmentos, caso del $\mathrm{n}^{\mathrm{o}} 1.009$ (fig. 8), entre otros, que ponen de manifiesto de forma clara una débil presencia de Bronce Final Reciente en este yacimiento.

\section{Cerámica Decorada}

Contamos con dos fragmentos decorados mediante distintos sistemas: acanaladuras e impresiones.

Uno de ellos corresponde a un fragmento de cazuela carenada cuya superficie exterior presenta un acabado poco cuidado, alisado tosco, mientras que la interior se encuentra alisada; la cocción es alternante y el desgrasante medio, con presencia de abundante mica plateada. Mide 6,5 mm. de espesor, es de tonalidad marrón en ambas caras y el diámetro, tomado en la línea de carenación, ha proporcionado una medida de $20 \mathrm{~cm}$. Presenta una decoración a base de acanaladuras muy suaves, que desarrollan ángulos en serie, insertos unos en otros, unidos por el vértice superior (fig. 7: 79).

El segundo ejemplar es un atípico de cerámica impresa e incisa, de superficies alisadas, cocción oxidante y desgrasante medio; mide $9 \mathrm{~mm}$. de grosor y es de tonalidad marrón tanto al exterior como al interior. Muestra una decoración a base de líneas oblicuas formando ángulos que se encuentran rellenos de impresiones circulares, de tamaño ancho y presión profunda (fig. 7: 511).

Por la forma del primer fragmento, cazuela carenada, y por la decoración que presenta el segundo, así como por sus características y factura, consideramos que estamos ante restos adjudicables al Calcolítico Inicial y Pleno, siendo frecuente en estos conjuntos la presencia de cerámicas decoradas mediante bandas en ángulo y triángulos rellenos de impresiones, temas decorativos que aparecen también en los recipientes que forman parte de los ajuares de enterramientos colectivos, tanto megalíticos como en cuevas artificiales. De manera que está en perfecta consonancia con el anterior conjunto analizado. 


\section{- Atípicos Sin Decorar}

Estos restos contabilizan el $43,15 \%$ del material que aquí analizamos procedente de este yacimiento. Seguidamente relatamos sus características generales.

\begin{tabular}{|c|c|c|}
\hline - Superficies: & Ext. & Int. \\
\hline Bruñida . . . & $1,37 \%$ & $(-)$ \\
\hline Espatulada & $(-)$ & $(-)$ \\
\hline Alisada Muy Fina . . . . & $1,37 \%$ & $0,68 \%$ \\
\hline Alisada Fina $\ldots \ldots$ & $8,96 \%$ & $3,44 \%$ \\
\hline Alisada . . . . . & $35,91 \%$ & $25,51 \%$ \\
\hline Alisada Tosca & $30,34 \%$ & $44,22 \%$ \\
\hline Tosca ..... & $17,24 \%$ & $21,37 \%$ \\
\hline Muy Tosca & $3,44 \%$ & $4,13 \%$ \\
\hline \multirow[t]{2}{*}{ Erosionada } & $1,37 \%$ & $0,69 \%$ \\
\hline & $\overline{100,00 \%}$ & $\overline{100,00 \%}$ \\
\hline
\end{tabular}

\begin{tabular}{|c|c|}
\hline Cocción: & \\
\hline Reductora & $26,89 \%$ \\
\hline Oxidante. & $34,50 \%$ \\
\hline Nervios. & $11,72 \%$ \\
\hline Alternante & $26,89 \%$ \\
\hline
\end{tabular}

\begin{tabular}{lr} 
- Desgrasantes: & \\
No Apreciables & $0,65 \%$ \\
Muy Finos . . . & $4,82 \%$ \\
Finos . . . . . & $17,93 \%$ \\
Medios . . . . & $44,89 \%$ \\
Gruesos . . . . & $22,06 \%$ \\
Muy Gruesos . & $9,65 \%$ \\
\hline
\end{tabular}

-Espesores:

$-6 \mathrm{~mm} . \quad 2,75 \%$

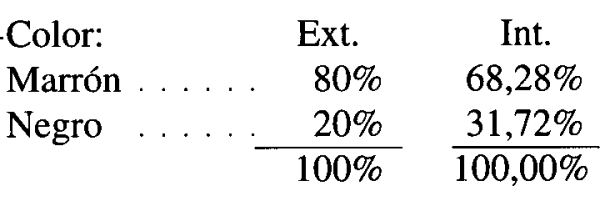

\section{Consideraciones generales sobre el material}

A tenor de lo expuesto en el análisis de los restos, contamos en este yacimiento con una ocupación neolítica, no muy intensa, pero sí significativa, con los restos cerámicos característicos de este período en sus fases Media y Final; dicha ocupación se intensifica, a juzgar por el número de restos, durante el Calcolítico Inicial, produciéndose un abandono de este lugar hasta su reocupación durante algún momento del Bronce Reciente, que cuenta, por el momento, también con una ocupación sólo testimonial.

En lo que se refiere a las cerámicas, queremos resaltar que las adjudicadas al Calcolítico presentan generalmente desgrasantes micáceos, que no aparecen entre las cerámicas decoradas que hemos analizado como correspondientes al Neolítico.

Por su parte, la industria lítica tallada corrobora la presencia de ambos períodos en el yacimiento. De un lado, contamos con determinados elementos que, si bien son más propios en ambientes epipaleolíticos (caso de las láminitas de borde abatido, las escotaduras, los denticulados, etc.), en ocasiones pueden estar presentes en conjuntos neolíticos debido a la existencia de un sustrato anterior, junto a otros de clara tipología neolítica, como la mayoría de las láminas retocadas; y de otro, con piezas típicamente calcolíticas, entre las que destacan los dientes de hoz, que manifiestan la continuidad de este lugar de hábitat.

Finalmente, hemos de indicar que la ocupación de este sitio no arranca en el Neolítico, sino que contamos con una industria lítica tallada en la que, aún en fase de estudio, parece detectarse la existencia de Paleolítico Medio y, sobre todo, un cuantioso volumen de items líticos tallados pertenecientes al 
Paleolítico Superior, que, como ya se ha apuntado, dan cuerpo a un trabajo independiente por la entidad que ofrecen estos restos.

Nada tiene de extraño, desde nuestra óptica, la reiterada ocupación de este sitio si tenemos en cuenta las magníficas condiciones que reúne para el hábitat. Está situado a unos $10 \mathrm{~km}$. del curso del Corbones, sobre una plataforma miocena de unos $200 \mathrm{~m}$. s./n.m., auténtica atalaya desde la que se controlan y dominan amplios terrenos llanos y de cuyo pie parten numerosos cursos fluviales menores, estando rodeada, además, de inmejorables tierras de labor.

\section{SAN PEDRO}

Se localiza en el subconjunto Norte de los Cerros de San Pedro, a $1 \mathrm{~km}$. del subconjunto Sur y, por lo tanto, de Los Alamos. En este sector de los Cerros de San Pedro, Fernández Caro (1992) ha detectado la existencia de cuatro puntos en los que aparecen restos de cerámicas pertenecientes a época prehistórica.

Del sector denominado por el citado investigador "San Pedro I", sólo analizamos aquí cuatro fragmentos cerámicos, todos ellos decorados. Algunos fueron dados a conocer por Fernández Caro (1992).

$\mathrm{N}^{\circ}$ 1.- Fragmento de borde, semiplano, de dirección saliente y diámetro no determinable. Ambas superficies han recibido el mismo tratamiento, alisado; la cocción es alternante y el desgrasante muy fino; mide $12,5 \mathrm{~mm}$. de espesor y es de tonalidad marrón tanto exterior como interiormente. Como S.P.S. presenta un mamelón redondeado macizo que parte del labio de la vasija. La decoración consiste en la capa de engobe que recubre totalmente la cara de la porción de fragmento conservado, abarcando dicho engobe el labio y el borde por el exterior. El color de este engobe es de tonalidad anaranjada (fig. 8).

$\mathrm{N}^{\circ}$ 2.- Fragmento atípico; la superficie exterior es alisada fina, y la interior alisada; la cocción es reductora y el desgrasante medio; mide $9 \mathrm{~mm}$. de espesor y el color es marrón tanto al exterior como al interior. La decoración consta de impresiones, de tamaño medio y ancho y presión profunda, que recuerdan lejanamente a los motivos basculantes (fig. 8).

$\mathrm{N}^{\mathrm{o}}$ 3.- Fragmento atípico; la superficie exterior es tosca y la interior alisada tosca; el fuego es alternante y el desgrasante grueso; mide $8,5 \mathrm{~mm}$. de espesor y es de tonalidad marrón a exterior y negruzca al interior. La decoración consiste en incisiones, medias y profundas, que forman líneas oblicuas separadas por una línea también oblicua pero en sentido inverso a las primeras (fig. 8).

$\mathrm{N}^{\circ}$ 4.- Fragmento atípico; superficie exterior alisada, interior alisada tosca; fuego oxidante y desgrasante muy fino; el espesor de la pared mide $8,5 \mathrm{~mm}$. y el color es de tonalidad marrón al exterior así como al interior. Ha sido decorado mediante una línea vertical incisa de la que parten acanaladuras oblicuas, de tamaño pequeño y presión media (fig. 8).

Además de estos materiales, conviene señalar la presencia de dos piezas pulimentadas -un hacha y una azuela-, un posible ídolo falange, piezas pasivas de molinos, fragmentos de cazuelas carenadas, algún plato de borde engrosado, fragmentos de cuencos de media esfera, abundantes fragmentos de cerámica campaniforme y, ya dentro del Bronce Pleno, Final y Orientalizante, una cantidad no desdeñable de carenas bajas, medias y altas (Fernández Caro 1992). 


\section{Consideraciones sobre el material}

Como resulta lógico, con esta escasez de material que aquí analizamos en profundidad bien poco podemos pronunciarnos al tratar sobre su adscripción cultural. Si embargo, teniendo en cuenta los motivos decorativos y la presencia del fragmento $\mathrm{n}^{\circ} 2$, cuyo tema decorativo recuerda a las impresas basculantes, planteamos la posibilidad de que se trate de restos cerámicos pertenecientes al Neolítico Medio y/o Final, siendo conscientes de que la evidencia es bastante frágil y de que podemos estar ante unos materiales cerámicos que, aunque característicos del Neolítico, perduran en la etapa siguiente. Así, pues, podríamos contar con una débil ocupación neolítica del sitio de San Pedro, ocupación que se prolonga e intensifica a lo largo del Calcolítico y Edad del Bronce en general.

\section{CONSIDERACIONES FINALES SOBRE LOS YACIMIENTOS ANALIZADOS}

Indiscutiblemente, los restos neolíticos presentes en estos yacimientos vienen a llenar un importante vacío en este sector de la campiña andaluza, y marcan el inicio sobre la investigación de una etapa cuya presencia hasta ahora era desconocida. Por otra parte, consideramos muy interesante el hecho de que estos yacimientos cuenten, entre los restos que han llegado hasta nosotros, con materiales adjudicables al Neolítico, Calcolítico, otros quizá al Bronce Pleno, escasamente documentado en todo este sector regional y aún mal definido precisamente por su exigüidad, y, por último, algunos, al Bronce Reciente.

Mediante la presencia de estos materiales no queremos indicar una total continuidad de hábitat, sin hiatos, en estos asentamientos, haciendo partir el sedentarismo desde época neolítica, sino hacer notar que las magníficas condiciones que rodean a estos yacimientos para el inicio y desarrollo de las actividades económicas de producción no fueron ajenas a ninguno de estos grupos humanos, teniéndose en cuenta, también, la proximidad de estos yacimientos al río Corbones, vía natural de comunicación.

De otro lado, nos evidencian, con restos adjudicables a etapas inmediatamente posteriores al Neolítico, que la notable ocupación de que es objeto la campiña, en general, a partir del Calcolítico se asienta sobre un sustrato anterior, neolítico, aunque por el momento sea de forma tímida, pero bien patente a juzgar por estos yacimientos que presentamos, ocupación que se acentúa con el Calcolítico Inicial y desemboca en el auge que se manifiesta durante la fase Plena de dicho período en la mayor parte de los terrenos llanos y abiertos, aunque nosotros tengamos escasamente documentada la referida fase en estos asentamientos del Corbones.

La situación de estos yacimientos, rodeados de excelentes tierras de labor, nos indica que podemos estar ante el comienzo de la explotación agrícola de las mismas, aunque no contemos con evidencias directas de cultivo, como resulta lógico tratándose de materiales procedentes de recogidas superficiales. Por otra parte, no debemos olvidar, junto a esta posible economía agrícola, otra ganadera, puesto que debemos tener en cuenta que las feraces tierras de la campiña contarían con abundante vegetación, arbórea y herbácea, que podría sustentar sobradamente las necesidades de una cabaña doméstica compuesta por un número no muy numeroso tanto de individuos como de especies.

Como indicamos, en estos asentamientos podría haberse llevado a cabo una economía tanto agrícola como gánadera, pero sin primar una sobre otra al no poseer datos que nos permitan determinar la mayor importancia de una de estas dos actividades económicas, considerando que la riqueza de los suelos que rodean a estos yacimientos no es razón suficiente para proponer el mayor desarrollo de una práctica agrícola frente a la ganadera.

Esta economía productora la suponemos complementada con la recogida de frutos y productos vegetales silvestres, así como con la caza de especies salvajes. Opinamos que tanto unos como otras 
debían ser variados en un medio como éste, junto al río. De otro lado, esta vía fluvial aporta, como materias primas susceptibles de explotación por parte de los distintos grupos humanos, pequeños nódulos de sílex, nunca mayores de $10 \mathrm{~cm}$., que vienen a corresponderse con el tamaño general que presenta la industria lítica tallada.

En otro orden de cosas, somos de la opinión de que la presencia de estos yacimientos, con unas cerámicas como las analizadas en páginas anteriores que resultan plenamente encuadrables en el Neolítico Medio y Final, pero situados en plena campiña andaluza, viene a señalar, una vez más, la total inconsistencia de seguir designando a este período con la denominación, desde hace tiempo totalmente inapropiada, de Cultura de las Cuevas con Cerámica Decorada, identificando con ella al Neolítico Medio, puesto que, como se ha puesto de manifiesto en algunos yacimientos en cueva, la cerámica no decorada llega a alcanzar unos porcentajes verdaderamente significativos, en ocasiones superiores a las decoradas, a lo que hay que sumar la detección de una cantidad nada desdeñable de yacimientos neolíticos al aire libre, como es el caso de los que aquí presentamos, el de Lebrija, en la misma provincia de Sevilla (Caro y otros 1986), los yacimientos onubenses (Piñón 1988), los detectados en Cádiz (Ramos y otros 1994), así como otros localizados en la campiña cordobesa, como pueden ser Guta, San Joaquín, la Polonia, etc. (Carrilero y Martínez 1985), o al aire libre en la Subbética cordobesa, como los recientemente detectados, aún en estudio, de El Castillejo de Carcabuey, Hoya de la Bolsa, Cerro del Cercado y Cerro de la Taberna y, ya en Andalucía Oriental, la Molaina (Sáez y otros 1981), número de yacimientos que, junto con otros que no hemos citado, estamos seguros irá aumentando conforme avancen los proyectos de investigación.

Consideramos, pues, que el Neolítico está presente desde sus comienzos, tanto al aire libre -en terrenos llanos y abiertos de campiña y valle y conjuntos serranos-, como en cuevas y abrigos rocosos, cuyas diferencias, dentro de la homogeneidad que presentan los conjuntos, deben entenderse como consecuencia del aprovechamiento de los distintos recursos que ofrece cada ecosistema, pero sin aceptar, salvo en puntuales casos, que el Neolítico serrano es retardatario y, económicamente, ganadero y cazador-recolector, frente al carácter dinámico y eminentemente agrícola del Neolítico de espacios abiertos.

En cuanto a las cerámicas cardiales presentes en la mayoría de los yacimientos situados en Andalucía Occidental, según lo publicado, hemos de decir que ofrecen un aspecto bien diferente, en cuanto a su calidad, del cardial levantino y granadino, representado éste principalmente por Carigüela, lo que podría indicar que, según las secuencias levantinas, estaríamos ante los momentos finales del cardial. De otro lado, consideramos que el escaso número de fragmentos decorados mediante cardium con que se cuenta en Andalucía Occidental, y en determinados yacimientos de la Oriental, tiende a sobrevalorarse en extremo, de tal manera que la sola presencia de un fragmento decorado con esta matriz, sirve de base para asegurar un Neolítico Antiguo, incluso para materiales descontextualizados, cuando la realidad, hoy por hoy y a tenor de los datos que se tienen, es que Andalucía Occidental no cuenta con un Neolítico Antiguo Cardial como el levantino y que, junto a las escasas impresas cardiales, se constata un número más que considerable de otras especies cerámicas decoradas mediante otros sistemas.

Consideramos que, antes de pronunciarnos a favor o en contra del binomio Neolítico Antiguo $=\mathbf{a}$ cerámica cardial en Andalucía Occidental, es necesario contar con más estratigrafías en las que esta especie esté presente en mayor cantidad, puesto que en los yacimientos excavados que cuentan con cardial ésta es, por el momento, demasiado escasa.

Al margen ya de todas estas cuestiones a las que nos acabamos de referir, creemos que la situación de estos yacimientos, en plena campiña sevillana, abre alentadoras perspectivas no sólo en lo que atañe al conocimiento del Neolítico en terrenos abiertos, sino en lo que se refiere a la penetración hacia el N. del Guadalquivir, y más concretamente a la mayor parte de Sierra Morena, de estas primeras 
comunidades productoras, donde, exceptuando la Cueva Chica de Santiago (Pellicer y Acosta 1982) y la Cueva del Cañaveralejo (Gavilán 1985), no se tienen noticias de yacimientos neolíticos. En este sentido, nos parece interesante la relación que manifiestan estos yacimientos con el curso fluvial del Corbones, que constituye, como ya hemos expuesto, una vía natural de comunicación entre el Surco Intrabético de la zona de Antequera y el Norte de la Depresión de Ronda con el Valle del Guadalquivir. Es por dicha vía por donde ha podido llegar el Neolítico a este sector de la campiña de Sevilla, dadas las semejanzas que guardan los restos procedentes de los yacimientos que aquí analizamos con los que han proporcionado otros, tanto en cueva como al aire libre, situados en las distintas serranías de Cádiz y las del sector noroccidental de Málaga. Junto a esta vía de penetración no podemos soslayar la que constituye la principal arteria fluvial andaluza, que cuenta, próxima a su actual desembocadura, con un número cada día más elevado de yacimientos con restos materiales semejantes a los nuestros, pudiendo llegar a compartir una unidad de identidad en este período.

En lo referente a las cazuelas carenadas -formas a las que suelen acompañar, entre otros elementos, puntas de flecha y dientes de hoz, útiles éstos ausentes en los conjuntos neolíticos contextualizados, en los que, por el contrario, sí aparecen "elementos de hoz", que definimos como útiles generalmente sobre hoja con doble truncadura-, consideradas por algunos investigadores como correspondientes al Neolítico Final, queremos decir que a nosotros nos parece más adecuada una adjudicación calcolítica, definiendo el comienzo de este período. En favor de esta hipótesis argumentamos un cambio significativo en la cultura material típicamente neolítica, como es la notable disminución que manifiestan las distintas técnicas decorativas, así como la aparición de una forma cerámica totalmente nueva -la cazuela carenada, junto con los ya mencionados dientes de hoz y puntas de flecha-, el acusado descenso de hojas de sílex de tamaño pequeño y su sustitución por otras de mayor longitud, el aumento de hachas y azuelas, el hábitat casi exclusivamente al aire libre, etc. Si bien es cierto que, aunque no con mucha frecuencia, aparecen algunas cazuelas carenadas en el interior de yacimientos en cueva, suelen ir asociadas a platos de borde engrosado, lo que resulta lógico si tenemos en cuenta que las primeras formas conviven con las segundas durante cierto tiempo. No creemos válido el argumento de la ausencia de elementos metálicos para admitir la adscripción al Neolítico de estos conjuntos industriales, puesto que de ser así tendríamos que considerar como neolíticos bastantes yacimientos, cultural y cronológicamente avanzados, en los que el metal o está ausente o es verdaderamente escaso y sólo tiene un valor testimonial, no asegurando su presencia el conocimiento de las técnicas metalúrgicas del grupo en cuestión.

Estamos de acuerdo, no obstante, en que la aparición de las cazuelas carenadas, "y los restantes conjuntos industriales que le acompañan, no marca una ruptura con respecto a la anterior tradición de las cerámicas decoradas, pero sí el inicio de una etapa nueva que, a la postre, va a significar un marcado cambio que se gestará y consolidará a lo largo del Calcolítico.

En cuanto a los patrones de asentamiento de estas primeras comunidades productoras establecidas en la zona que nos ocupa, poco es lo que podemos apuntar por el momento hasta que no se cuente con mayor número de yacimientos, no obstante, cabe señalar que se localizan en zonas elevadas, sobre todo Los Alamos y San Pedro, con puntos de agua cercanos y situados en torno a la red fluvial principal de este sector, el río Corbones, próximo ya a su desembocadura en el Guadalquivir.

De otro lado, la corta distancia existente entre unos yacimientos y otros $-11 \mathrm{~km}$. entre Las Barrancas y Los Alamos, y $1 \mathrm{~km}$. entre éste y San Pedro I- y la homogeneidad de los restos materiales aportados por cada uno de ellos, nos sugiere la hipótesis, en caso de ser sincrónicos, de una alternancia en la ocupación, temporal, de estos lugares, al menos entre Las Barrancas y Los Alamos, que suponemos en función del aprovechamiento de recursos de diverso orden, así como, posiblemente, del agotamiento de las tierras más fácilmente cultivables y próximas al hábitat, si hubo una práctica agrícola. 
Por su parte, la cercanía existente entre Los Alamos y San Pedro, y el hecho de constituir el primero un subconjunto -Sur- del conjunto de los Cerros de San Pedro -Norte-, parece indicar, más que la existencia de dos yacimientos independientes o el traslado de parte de la población a otro sector del conjunto en un momento determinado del Neolítico, el inicio del hábitat en San Pedro a partir del final del Neolítico o, más bien, del comienzo del Calcolítico Inicial, si tenemos en cuenta el escaso material con posibilidades de adscripción al Neolítico que ha proporcionado este lugar en contraposición al volumen de registros correspondientes al comienzo del siguiente período.

Aunque no está dentro de los objetivos que nos proponemos en este trabajo, cuyo motor principal ha sido el dar a conocer los restos neolíticos, nos parece necesario hacer una breve referencia a la perduración que manifiestan los distintos yacimientos aquí analizados, remitiendo al trabajo de Fernández Caro (1992) para una mayor documentación al respecto.

Hemos de decir que siempre nos ha resultado difícil de explicar la eclosión poblacional y ocupacional de la casi totalidad de las tierras de valle y de campiña a partir del Calcolítico sin una base anterior, así que, a través de estos yacimientos, con un Neolítico rico y variado, al menos en el caso de Las Barrancas y Los Alamos, con los elementos cerámicos característicos de este período en nuestra región, debe deducirse que no existen verdaderos vacíos de población, sino desconocimiento por falta de trabajos científicos sistematizados, y que esa eclosión ocupacional que se manifiesta en el Calcolítico tiene, como ya hemos expuesto, una etapa previa que se inicia en el Neolítico, constituyendo éste el sustrato sobre el que se desenvuelve aquél.

Así, pues, en lo que a la continuidad de estos lugares de hábitats en etapas posteriores al Neolítico se refiere, basándonos en los materiales con que contamos, los yacimientos que aquí se analizan se comportan de manera diferente según los casos.

En Las Barrancas, tras el inicio del hábitat durante el Neolítico Medio y Final, se asiste a un abandono del mismo si tenemos en cuenta la ausencia de formas cerámicas claras y definitorias de las distintas fases del Calcolítico, habiendo aportado, por el contrario, unos materiales de raigambre calcolítica que podríamos interpretar, probablemente, como pertenecientes a etapas ya más avanzadas, dentro del Bronce Pleno, afín al que se ha documentado dentro de la zona que estamos analizando, como San Pedro o La Platosa V (Fernández Caro 1992), y en zonas próximas (Amores 1982).

Una dinámica diferente nos manifiestan los yacimientos situados en el conjunto de los Cerros de San Pedro -Los Alamos y San Pedro-, donde observamos cómo en todo este conjunto de cerros están presentes las cazuelas carenadas, que indican una continuidad del hábitat durante el inicio del Calcolítico; continuidad que se nos manifiesta bastante intensa en lo que a la ocupación de este sitio se refiere a juzgar por el porcentaje nada desdeñable de las citadas vasijas. Somos de la opinión de que el primigenio hábitat neolítico de Los Alamos perdura durante el Calcolítico Inicial, momento tras el que debió abandonarse hasta el Bronce Final, adelantando la hipótesis de que parte de la población pudiera trasladarse al subconjunto Norte, al sitio denominado San Pedro, cuyos materiales testimonian su actividad en estos momentos y mantiene una perduración hasta tiempos históricos.

La escasez de elementos propios del Calcolítico Pleno en San Pedro, ausentes en Los Alamos, no nos permite pensar en una ocupación intensa de estos sitios durante dicha fase, sobre todo en el segundo de ellos, que parece abandonarse durante un espacio de tiempo bastante prolongado.

El final del Calcolítico se nos manifiesta con bastante pujanza en San Pedro mediante la presencia de abundantes campaniformes de diferentes estilos. La presencia de esta especie cerámica en este sector del conjunto de los Cerros de San Pedro, y su ausencia en Los Alamos, podría indicar, como ya se ha comentado, un abandono de este sector -subconjunto Sur-, trasladándose la población al subconjunto Norte -San Pedro-, sector que, por otra parte, cuenta con determinados elementos cerámicos que podrían 
situarse en el Bronce Pleno, período éste que, como en la mayor parte de Andalucía Occidental, manifiesta también en esta zona una fuerte recesión.

Tras las débiles evidencias con que contamos que podrían adscribirse a ese Bronce Pleno, de raíz arcaizante, presentes en Las Barrancas y en San Pedro, en el Bronce Final, documentado en los tres yacimientos analizados, asistimos a un auge considerable desde su inicio.

En definitiva, nos encontramos ante unos yacimientos, situados en plena campiña, que cuentan con una fuerte ocupación neolítica en dos de los casos - Las Barrancas y Los Alamos-, que no deben corresponder a yacimientos de tipo campamento de paso, sino a auténticos lugares de hábitats, constituyendo el sustrato sobre el que se desarrolla ampliamente el Calcolítico, restringiéndose durante el Bronce Pleno, como viene siendo una norma común a todo este sector, para florecer de nuevo durante el Bronce Final.

\section{BIBLIOGRAFÍA}

ACOSTA, P. y PELLICER, M. (1990): La Cueva de la Dehesilla (Jerez de la Frontera). Las primeras civilizaciones productoras en Andalucía Occidental. Jerez de la Frontera.

AGUAYO, P. y otros (1988): "Excavaciones arqueológicas en el casco antiguo de Ronda (Málaga). Agosto de 1984", A.A.A./ 1985, III. Actividades de Urgencia: 236-239. Sevilla.

AMORES, F. (1982): Carta arqueológica de Los Alcores (Sevilla). Sevilla, Excma. Dip. Prov. de Sevilla.

BAENA, R. (1993): Evolución cuaternaria (3 m.a.) de la Depresión del Medio-Bajo Guadalquivir y sus márgenes (Córdoba y Sevilla). Tesis doctoral inédita.

BAGOLINI, B. (1968): "Ricerche sulle dimensione dei manifatti litici preistorici non riticcati", Annali dell'Univertita di Ferrara, Sezione XV, Vol. I, 10: 195-219.

CARO, A. y otros (1986): "Informe sobre la Prospección Arqueológica con Sondeo Estratigráfico en el Solar de la Calle Alcazaba (Lebrija-Sevilla)", A.A.A. II. Actividades Sistemáticas: 168-173.

CARRILERO, M. y MARTÍNEZ, G. (1985): "El yacimiento de Guta (Castro del Río, Córdoba) y la Prehistoria Reciente de la Campiña cordobesa", C.P.U. Gr. 10: 187-223.

FERNÁNDEZ CARO, J.J. (1992): Carta arqueológica del término de Fuentes de Andalucía (Sevilla). Ayuntamiento de Fuentes de Andalucía.

GAVILÁN, B. (1985): "Materiales prehistóricos de la Cueva del Cañaveralejo (Adamuz, Córdoba)." Ifigea II: 53-77. Córdoba.

— y VERA, J.C. (1992): "Breve avance sobre los resultados obtenidos en la excavación arqueológica de urgencia en la Cueva de los Murciélagos de Zuheros (Córdoba)." Antiqvitas 3: 23-30. Museo Histórico Municipal de Priego de Córdoba.

JORDÁ, F. y otros (1986): Prehistoria. Historia de España, 1. Madrid, Gredos.

MARTÍN DE LA CRUZ, J.C. (1994): El Tránsito del Neolítico al Calcolítico en el Litoral del SurOeste Peninsular (E.A.E. 169). Madrid, Ministerio de Cultura.

NAVARRETE, Ma .S. (1976): La Cultura de las Cuevas con Cerámica Decorada en Andalucía Oriental. Univ. de Granada.

PELLICER, M. (1964): El Neolítico y el Bronce de la Cueva de la Carigüela de Piñar (Granada), T.P. XV. Madrid.

— y ACOSTA, P. (1982): "El Neolítico Antiguo en Andalucía Occidental", Colloque Néolithique Ancien. Montpellier (1981): 49-60. Montpellier.

PIÑÓN, F. (1988): "El poblamiento neolítico de la orla litoral onubense: estado de la cuestión", Actas del I. Congreso Internacional del Estrecho de Gibraltar (Ceuta, 1987). Madrid: 221-253. 
RAMOS, J. (1988-89): "Las industrias líticas del Neolítico en Andalucía, sus implicaciones espaciales y económicas." Zephyrus XLI-XLII: 113-148.

y otros (1992): "Tecnología lítica de las Edades del Cobre y Bronce en la Marisma del Cuervo (Jerez de la Frontera, Cádiz)", Spal 1: 151-177.

(1994): "Aproximación al poblamiento Neolítico de San Fernando (Cádiz). Inferencias socioeconómicas y enmarque en el contexto regional", Antiquitas 5: 13-21. Museo Histórico Municipal de Priego de Córdoba.

RODRÍGUEZ TEMIÑO, I. (1984): Carta arqueológica del Río Corbones. Sevilla, Memoria de Licenciatura inédita.

SÁEZ, L. y MARTÍNEZ, G. (1981): "El yacimiento neolítico al aire libre de la Molaina (Pinos-Puente, Granada)." C.P.U.Gr. 6: 17-34. 


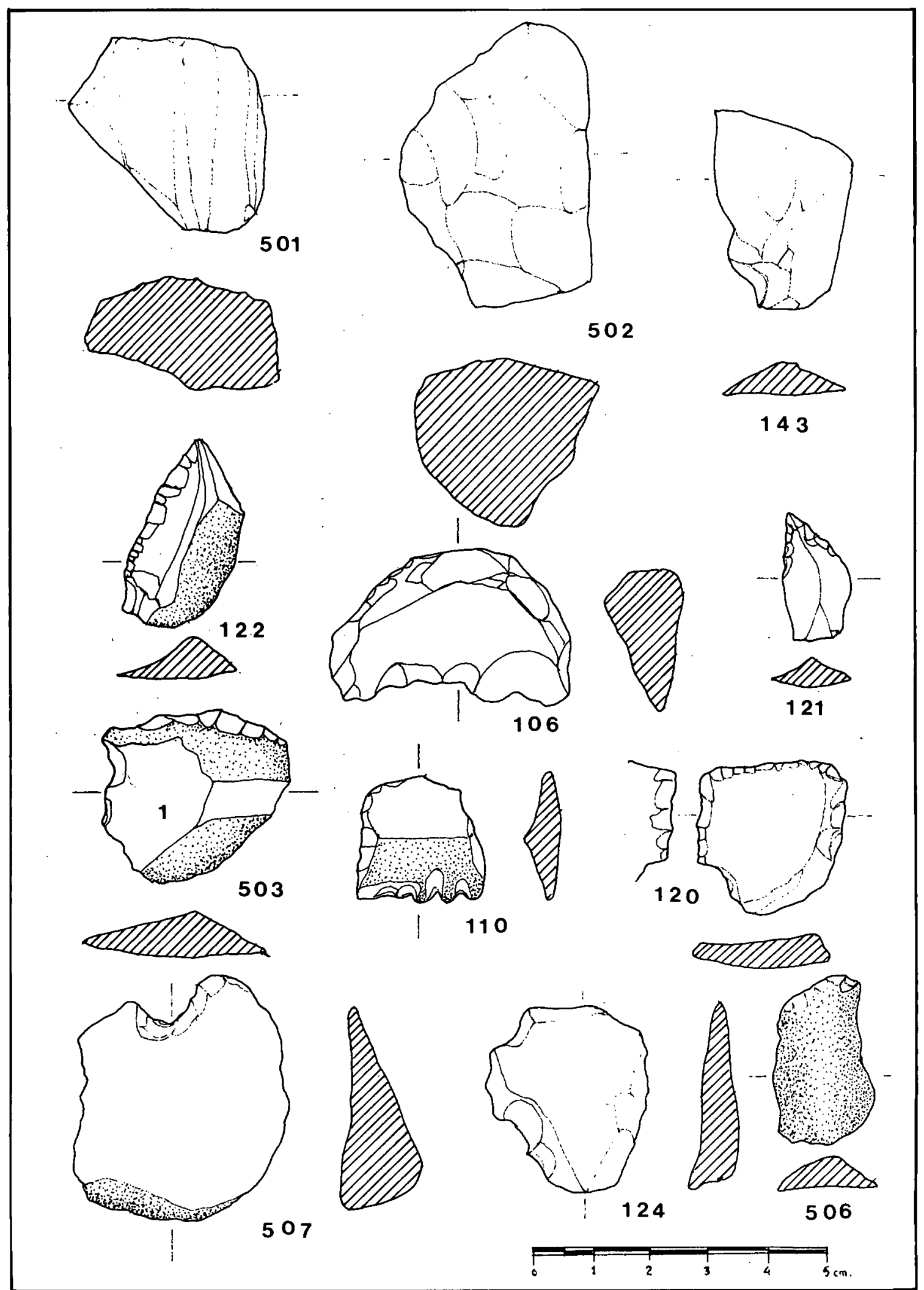

Fig. 1.- Las Barrancas. Material lítico. 


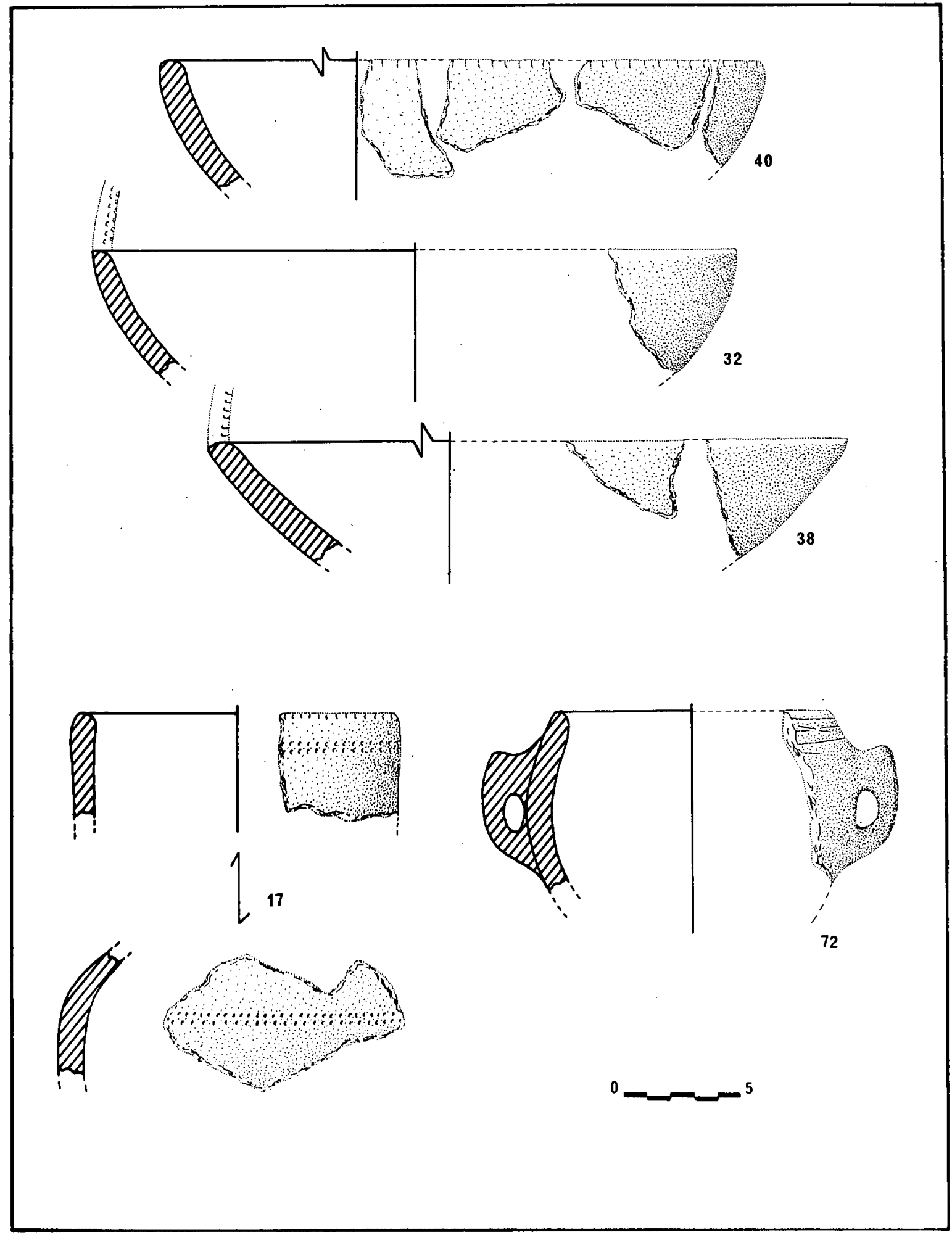

Fig. 2.- Las Barrancas. Material neolítico. 


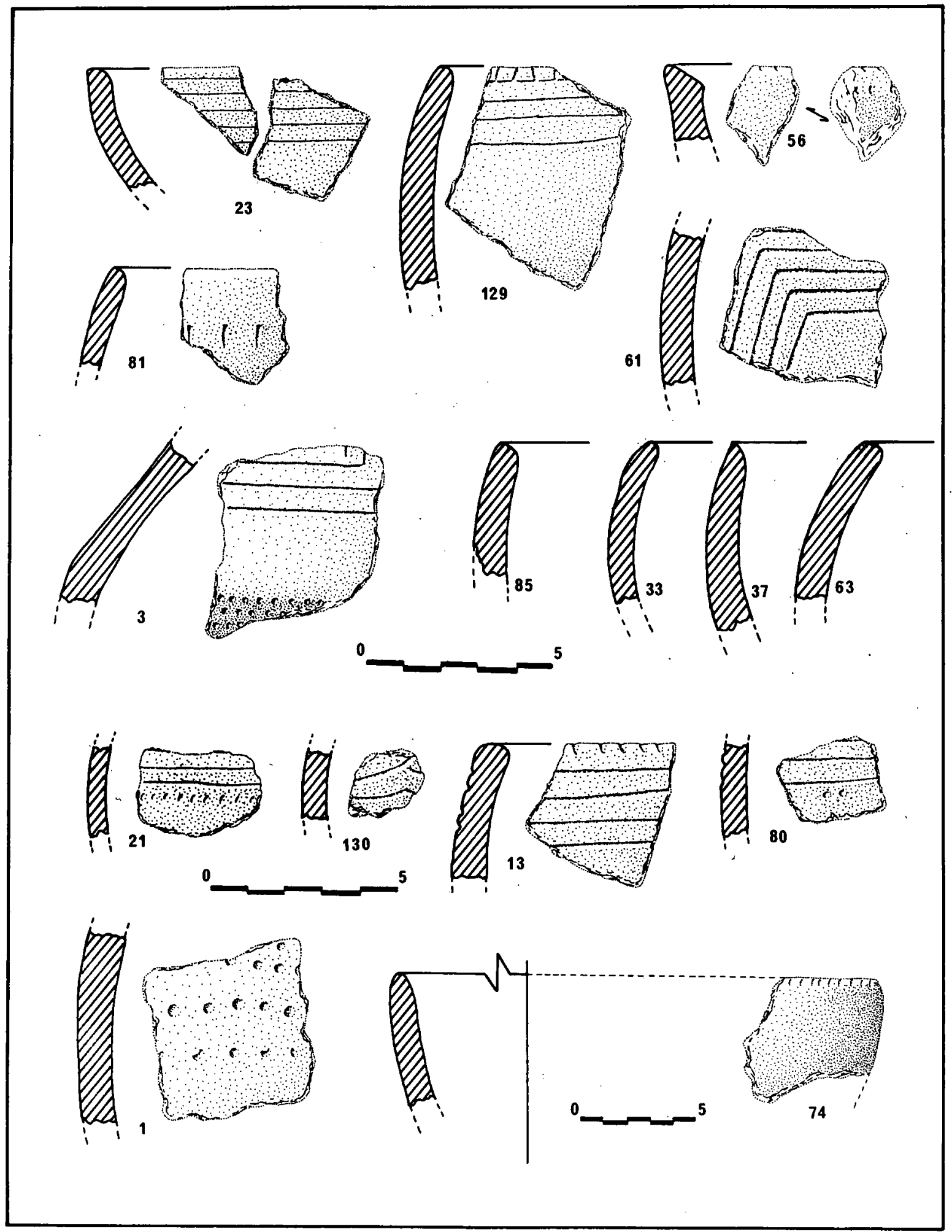

Fig. 3.- Las Barrancas. Material neolítico. 


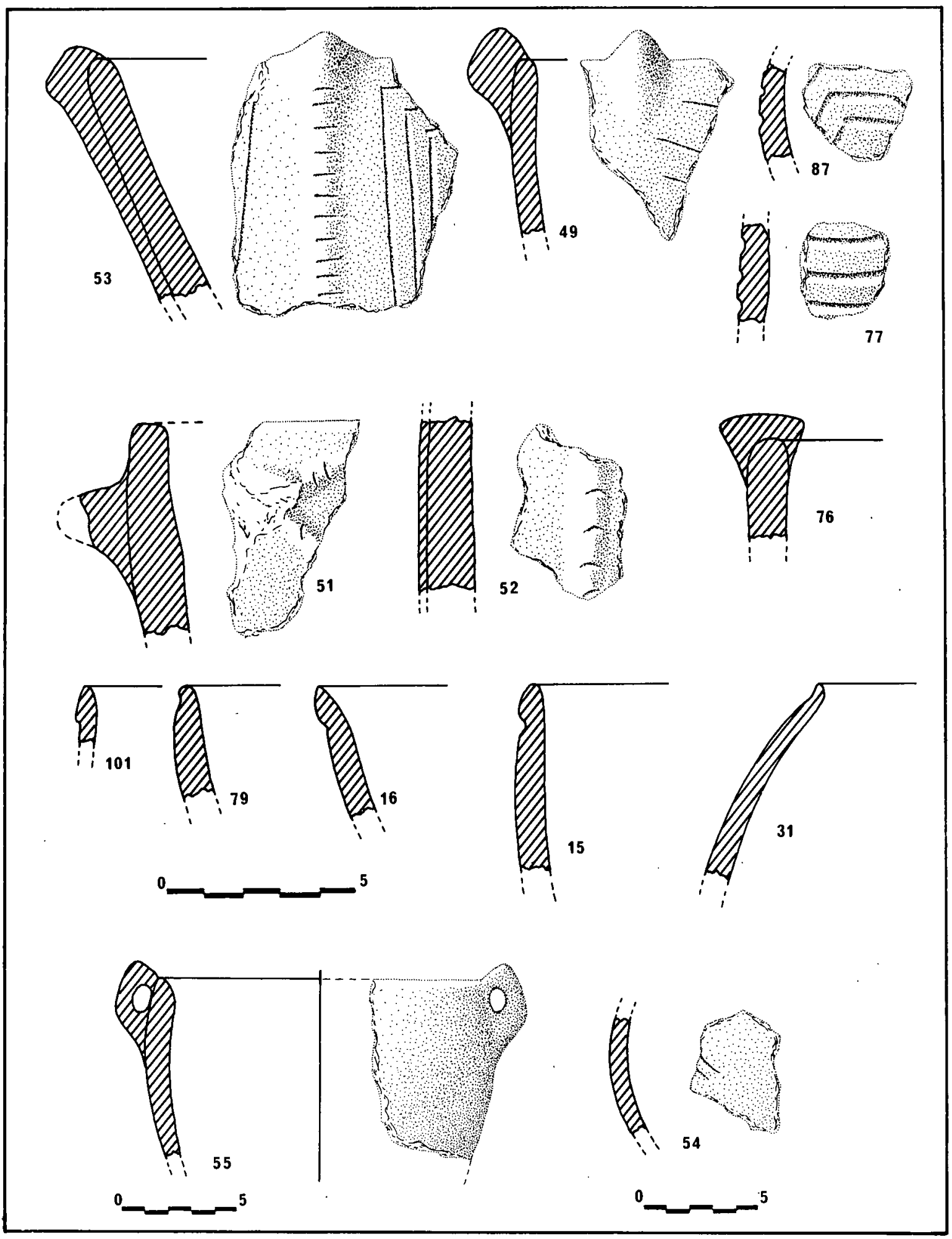

Fig. 4.- Las Barrancas. Material neolítico. 


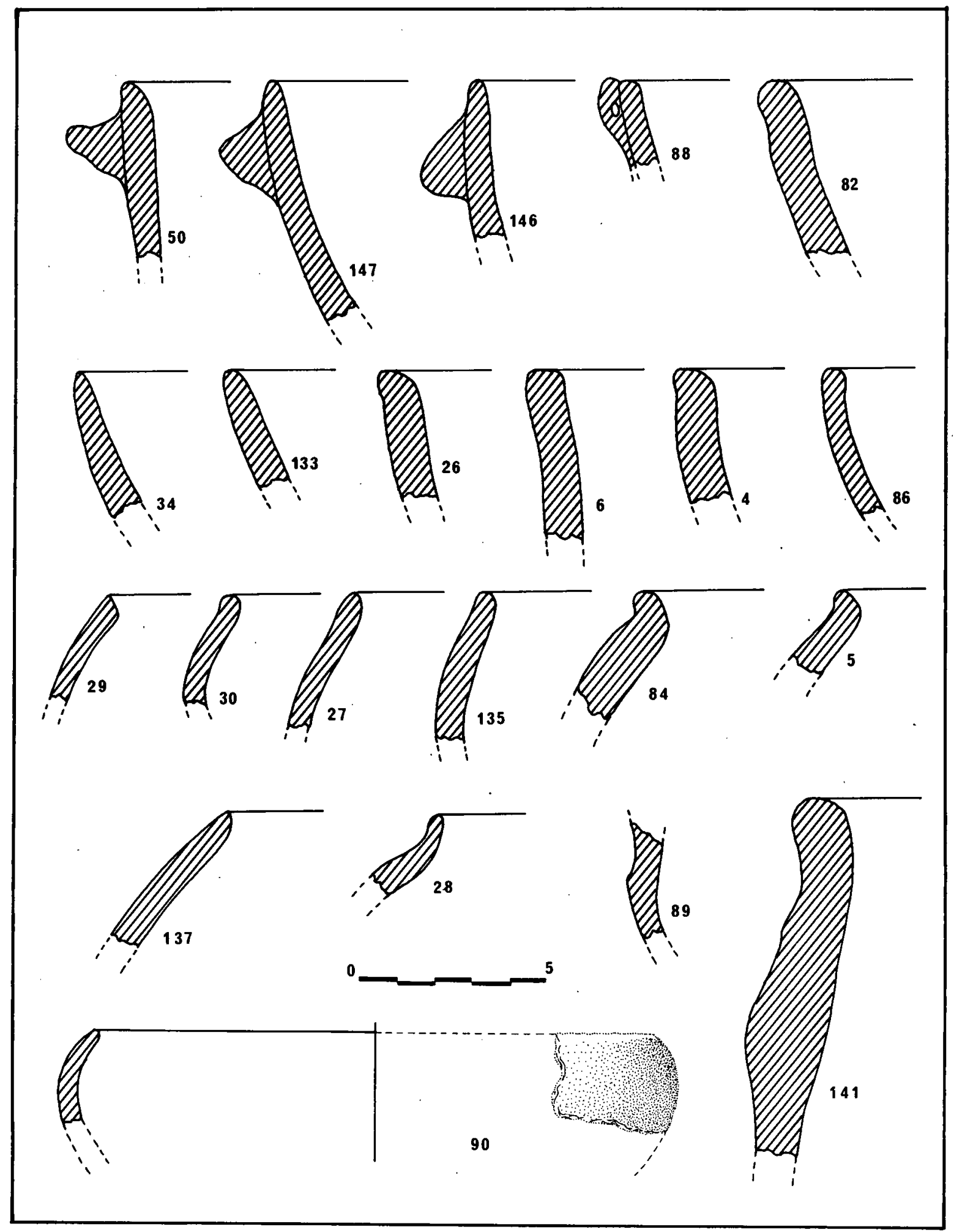

Fig. 5.- Las Barrancas. Material calcolítico y del Bronce. 


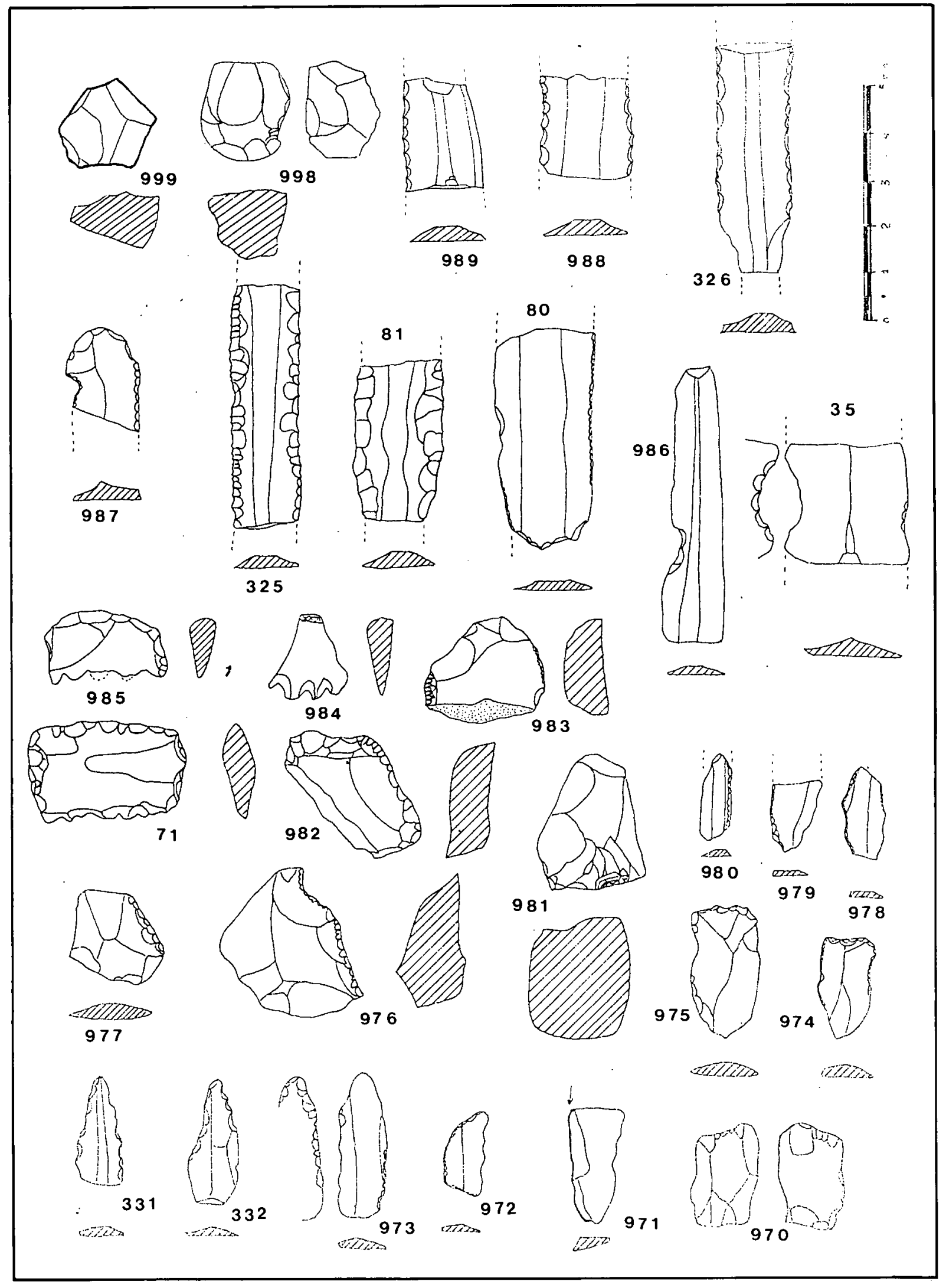

ISSN: $1133-4525$ ISSN-e: 2255-3924

SPAL 4 (1995)

http://dx.doi.org/10.12795/spal.1995.i4.02 


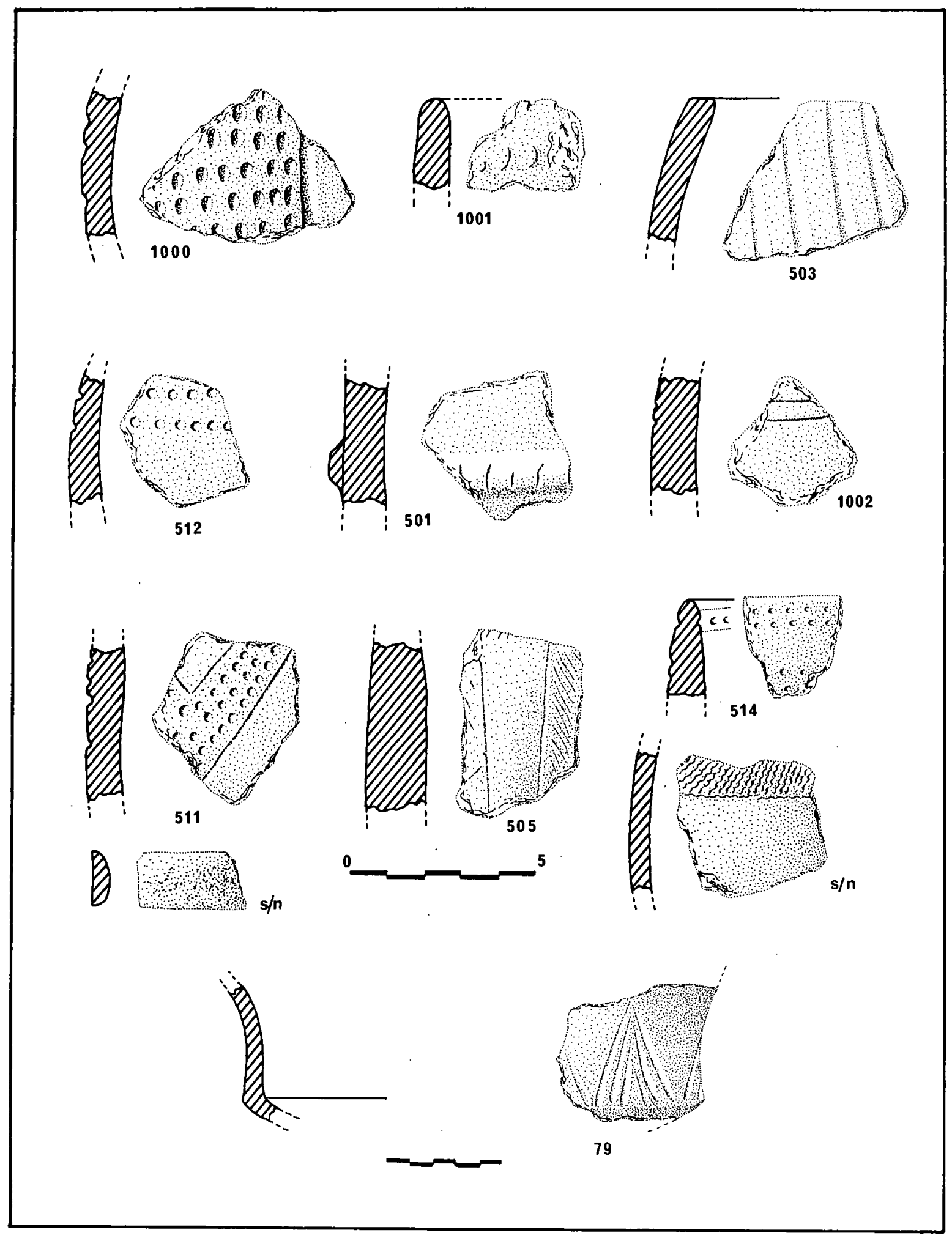

Fig. 7.- Los Alamos. Material neolítico y calcolítico. 


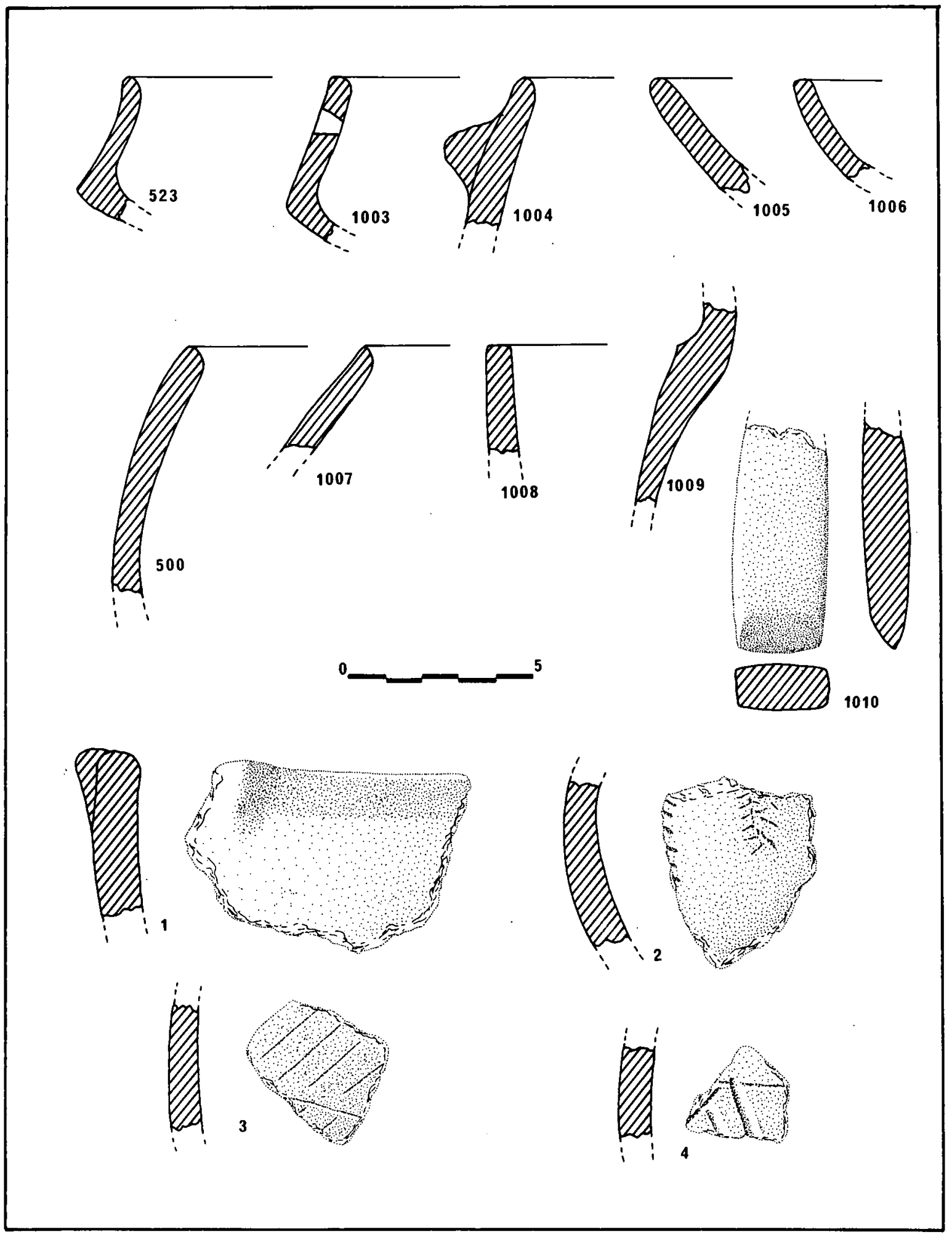

Fig. 8.- Los Alamos. Material calcolítico y del Bronce. San Pedro. Material cerámico. 